*ak RMIS View/Frint Document Cover Sheet tow

This document was retrieved from the Documentation and Records Manaqement (DRM) ISEARCH System. It is intended for Information only and may not be the most recent or updated version. Contact a Document Service Center (see Hanford Info for locations) if you need additional retrieval information.

Accession \#: D196058494

Document \#: SD-SNF-SP-010

Title/Desc:

SNF PROJECT DOSE MGMT PLAN

Pages: 57 


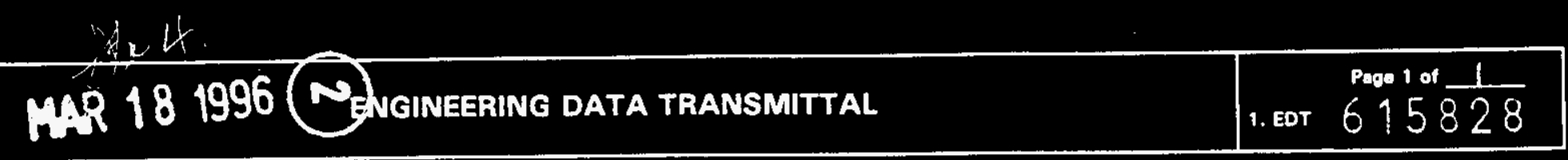

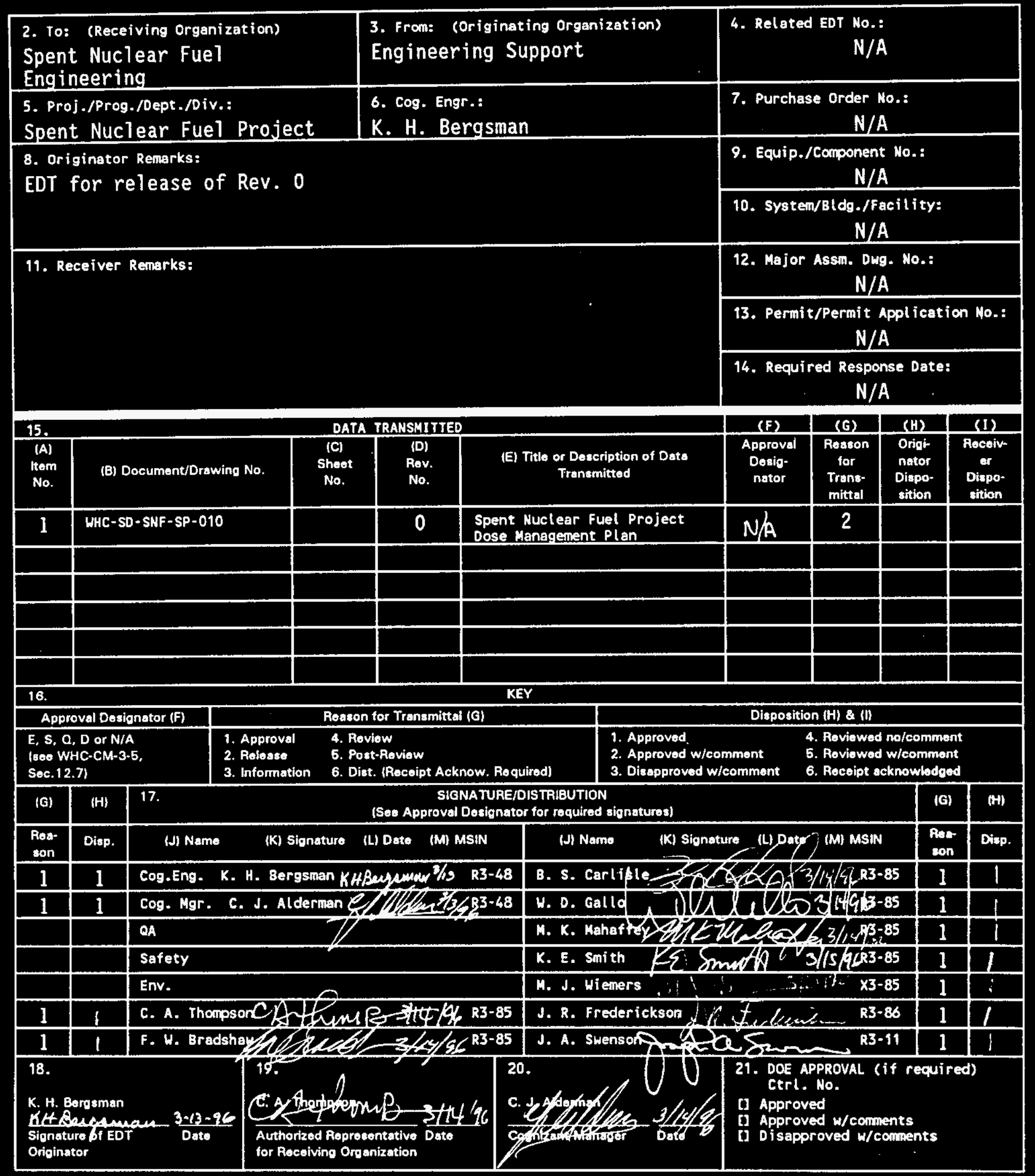

BD-7400-172-2(04/94) GEF097 
SPENT NUCLEAR FUEL PROJECT DOSE MANAGEMENT PLAN

K. H. Bergsman

WHC, Richland, WA 99352

U.S. Department of Energy Contract DE-AC06-87RL10930

EDT/ECN: $615828 \quad$ UC: 510

Org Code: 2C500 Charge Code: LBO49

B\&R Code: EW3135040 Total Pages: $5053 \mathrm{kms}$. 3/s/ths

Key Words: Dose Management, ALARA, Facility Design, Spent Nuclear Fuel

Abstract: This dose management plan facilitates meeting the dose management and ALARA requirements applicable to the design activities of the Spent Nuclear Fuel. Project, and establ ishes consistency of information used by multiple subprojects in ALARA evaluations. The method for meeting the ALARA requirements applicable to facility designs involves two components. The first is each Spent Nuclear Fuel Project subproject incorporating ALARA principles, ALARA design optimizations, and ALARA design reviews throughout the design of facilities and equipment. The second component is the Spent Nuclear Fuel Project management providing overall dose management guidance to the subprojects and oversight of the subproject dose management efforts.

TRADEMARK DISCLAIMER. Reference herein to any specific commercial product, process, or service by trade nane, tradenark, manufacturer, or otherwise, does not necessarily constitute or iniply its endorsement, recommendation, or favoring by the United States Government or any agency thereof or its contractors or subcontractors.

Printed in the United States of America. To obtain copies of this document, contact: WHC/BCS Document Control Services, P.0. Box 1970, Mailstop H6-08, Richland WA 99352, Phone (509) 372-2420; Fax (509) 376-4989.
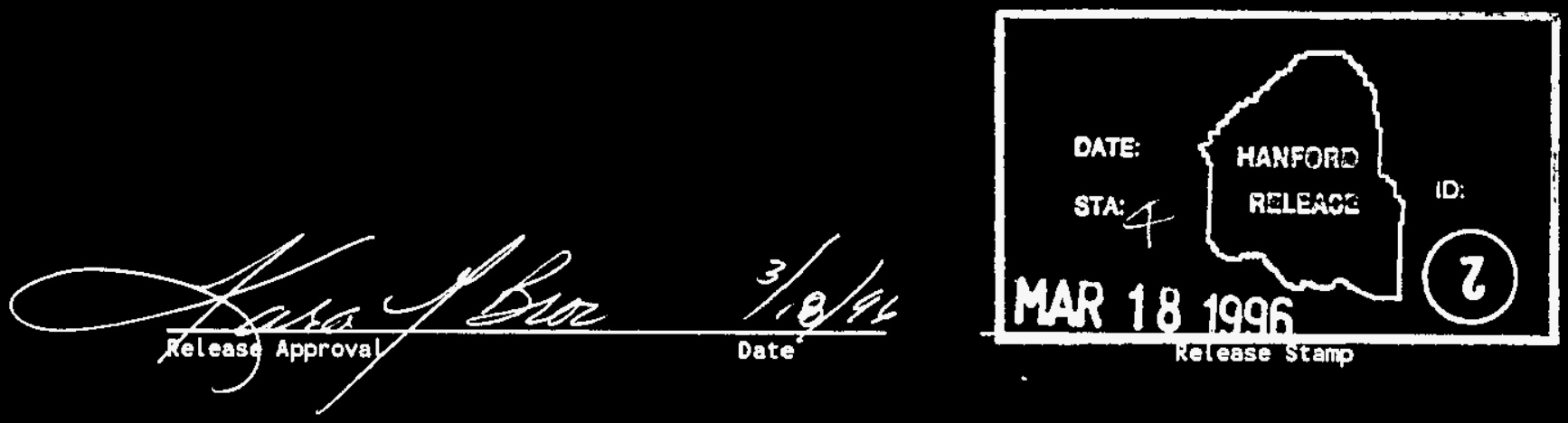

Approved for Public Release 
WHC-SD-SNF-SP-010, Rev. 0

\section{SPENT NUCLEAR FUEL PROJECT dOSE MANAGEMENT PLAN}

Table of Contents

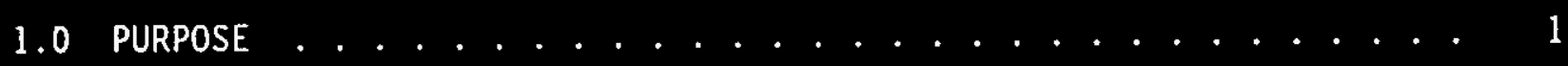

$2.0 \quad \operatorname{SCOPE} \ldots \ldots \ldots \ldots \ldots$

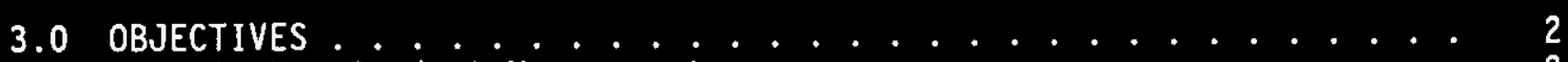

3.1 Senior Project Management ............. 2

3.2 Subproject Management .............. 2

4.0 ALARA Principles in Facility Design ........... 3

4.1 ALARA Requirements and Guidance........... 3

4.1.1 10 CFR 835 ALARA Design Requirements and Guidance . . 4

4.1.2 HSRCM-1 ALARA Design Requirements and Guidance.... 5

$\begin{array}{ll}\text { 4.1.2.1 Article 128: Facility Modifications and } & \\ \text { Radiological Design Considerations.... . } 5\end{array}$

4.1.2.2 Article 311: Planning Radiological Work, 2.66

4.1.2.3 Article 312: Planning for Maintenance,
Operations and Modifications . . . 6

4.1.2.4 Article 313: Infrequent or First-Time

4.1.2.5 Article 316: Minimization of Internal Exposure 7

4.1.2.6 Article 711: Radiological Records Requirements, Purpose ............ 8

4.1.3 SNF Project ALARA Design Requirements and Guidance : . 8

4.2 Design Optimization for ALARA . . . . . . . . . 8

4.2.1 Level of Effort . . . . . . . . . . . 8

4.2 .2 Methodology ................ 9

4.3 ALARA Design Review . . . . . . . . . 9

5.0 Overall Project Dose Management ............. 10

5.1 Dose Management Team .............. 11

5.2 Dose Management Performance Indicators ........ 12

6.0 GLOSSARY ......................... 12

7.0 References ........................... 15

APPENDIX A. ALARA Optimization and Design Review Forms ........ 17

A.1 Westinghouse Hanford Company Optimization Methodology . . . A-1

A.2 Appendix $3 A$ of the Hanford Site Radiological Control Manual Checklist for Reducing Occupational Radiation Exposure . . . A-27

A.3 ALARA Design Review Checklist ............ A-29 


\section{List of Terms}

ALARA

CFR

CSB

CVD

DAC

DMT

DOE

HSRCM

HVC

$\mathrm{keV}$

$\mathrm{MeV}$

PNL

SfHF

WHC

As Low As Reasonably Achievable Code of Federal Register canister storage building cold vacuum drying derived air concentration Dose Management Team U.S. Department of Energy Hanford Site Radiological Control Manual hot vacuum conditioning thousand electron volts million electron volts

Pacific Northwest Laboratory neutron quality factor spent nuclear fuel Westinghouse Hanford Company 
WHC-SD-SNF-SP-010, Rev. 0

\section{SPENT NUCleAR FUEL PROJECT dOSE MANAgeneNT PLAN}

\subsection{PURPOSE}

Application of As Low As Reasonably Achievable (ALARA) principles are a required part of all Hanford Site radiological activities (10 CFR 835, HSRCM1. WHC 1995). As defined in these documents, ALARA is an approach to radiological control that is intended to manage and control both individual and collective exposures to the work force and to the general public at levels as low as reasonable, taking into account social, technical, economic, practical, and public policy considerations. ALARA is a process; it is not a dose limit or a set of specific radiological control requirements.

The purpose of this document is to facilitate meeting the dose management and ALARA requirements applicable to the design activities of the Spent Nuclear Fuel (SNF) Project, and to establish consistency of information used by multiple subprojects in ALARA evaluations. As described herein, the method for meeting the ALARA requirements applicable to facility designs involves two components. The first component is the subproject managers, design authorities and design agents incorporateing ALARA principles, ALARA design optimizations, and ALARA design reviews throughout the design of facilities and equipment. The second component is the SNF Project management providing overall dose management guidance to the subprojects and oversight of the subproject dose management efforts.

This dose management plan is not an ALARA Plan, and as such, has no statutory requirements in itself.

\subsection{SCOPE}

The scope of this document is the management of the ALARA process applied to the design activities of the SNF Project, excluding those supporting maintenance and operations. Activities included are:

designs for systems at the $K$ Basins for removing all SNF, debris, and sludge, and for treating pool water;

designs for constructing, as necessary, new systems and facilities to condition and store the SNF prior to final disposition, including the Multi-Canister Overpack, the Cold Vacuum Drying Module (CVD), the Canister Storage Building (CSB), and the Hot Vacuum Conditioning facility (HVC);

designs for equipment used to relocate $K$ Basins SNF to the interim storage facility, including the cask transport equipment;

Non-design activities of the SNF Project are outside of the scope of this document, as are specific radiological control design requirements. Non-design activities include maintaining and operating the $K$ Basins, the new facilities, and the transport equipment. Specific radiological control design requirements and guidance are included in numerous documents, some of which are identified in Section 4.0 
This document applies to all organizations and personnel that design or construct facilities for the SNF Project, in which radiological work will be performed.

In this document, the capitalized words "SHALL" and "SHOULD" are used with the requirements and guidance that are extracted from Title 10 Code of Federal Register Part 835, Occupational Radiation Protection (10 CFR 835) or from the Hanford Site Radiological Control Manual (HSRCM-1). The uncapitalized words "shall" and "should" are used with requirements and guidance from the SNF Project Management.

\subsection{OBJECTIVES}

The objectives of the SNF Project Dose Management Plan are to:

1. Ensure that human and environmental exposures to radiological hazards or conditions, commensurate with sound economic and operating practices, are optimized during the design and construction of facilities and facility modifications.

2. Increase the ALARA awareness and understanding of personnel supporting the SNF Project process development and facility designs to simplify compliance with ALARA requirements and guidance.

3. Ensure that subproject designs and evaluations consider impacts on interfacing subprojects and make decisions that optimize SNF Project-wide impacts.

4. Ensure the consistency of bases and assumptions used in evaluations that affect radiological hazards and are used by more than one project area.

\subsection{Senior Project Management}

1. Provide the monetary resources to accomplish the objectives and design requirements or, in the case of WHC contractual requirements, the authorization to waive an objective or requirement. (Statutory requirements cannot be waived by project management.)

2. Ensure overall project ALARA optimization, by providing overall dose management guidance to the subprojects and oversight of the subproject dose management efforts, and by resolving conflicts between individual subprojects optimizations, when necessary.

\subsection{Subproject Management, Design Authorities and Design Agents}

1. Ensure that optimization techniques are used and documented in developing and justifying facility design and physical controls, to assure that occupational exposure is maintained ALARA.

2 Ensure that subproject designs and evaluations consider impacts on interfacing subprojects and make decisions that optimize SNF Project-wide impacts.

3. Ensure that the radiological design criteria of Section 4.1 are met by the evaluated alternatives. 
4. Ensure that the level of effort involved in developing and documenting ALARA decisions is commensurate with the costs and potential dose savings to be realized.

5. Ensure that major design reviews include evaluation of ALARA principles, beginning no later than the conceptual design stage and as early as the development of functions and requirements.

\subsection{ALARA Principles in Facility Design}

There are a number of documents that identify requirements and guidance relevant to including ALARA principles in the design of radiological facilities. These include:

The Title 10 Code of Federal Regulations Part 835, Occupational Radiation Protection (10 CFR 835), that codifies existing DOE radiation protection directives and provides nuclear safety requirements which, if violated, will provide a basis for the assessment of civil and criminal penalties under the Price-Anderson Amendments Act of 1988. (10 CFR 835 is available electronically in Hanford Information, as an Appendix to the Hanford Site Radiological Control Manual listed below.)

The Hanford Site Radiological Control Manual (HSRCM-1), that provides the contractual requirements for a Westinghouse Hanford Company ALARA program and is a site-wide manual consistent with the DOE Radiation Control Manual (DOE 1994). (HSRCM-1 is available electronically in Hanford Information.)

The WHC Occupational ALARA Program, provides a description of each of the elements that are to be considered for an occupational ALARA program, including radiological design review and optimization methodology (WHC 1995).

The ALARA requirements and guidance found in these documents on facility design are discussed in this Dose Management Plan. A useful reference with background information on ALARA principles is the Health Physics Manual of Good Practices for Reducing Radiation Exposure to Levels that are As Low As Reasonably Achievable (ALARA), (PNL 1988).

Requirements and guidance on general radiological design are also contained in these and other documents, including the Radiological Design Guide (Evans 1994); General Design Criteria, DOE Order 6430.1A (DOE 1988); Radiation Protection of the Public and the Environment, DOE Order 5400.5 (DOE 1990); and Radioactive Waste Management, DOE Order 5820.2A (DOE 1988). The requirements and guidance found in these documents are not specificaliy identified in this Dose Management Plan. Subproject managers, design authorities and design agents should ensure that facility designers consult these documents, comply with their requirements, and consider their guidance.

\subsection{ALARA Requirements and Guidance in Design}

The following ALARA requirements and guidance taken directly from 10 CFR 835 and the HSRCM-1 except as noted, shall apply. Modifications to the wording in 10 CFR 835 and HSRCM-1 are both italicized and enclosed in 
WHC-SD-SNF-SP-010, Rev. 0

parentheses. Subproject managers, design authorities, and design agents have responsibility to ensure that they are included in designs.

\subsubsection{CFR 835 ALARA Design Requirements and Guidance}

1. Measures SHALL be taken to maintain radiation exposure in controlled areas ALARA through facility design and equipment design and administrative control. The primary methods used SHALL be physical design features (e.g., confinement, ventilation, remote handling, and shielding). Administrative controls and procedural requirements SHALL be employed only as supplemental methods to control radiation exposure [10 CFR 835.1001 (a)].

2. For specific activities where use of physical design features are demonstrated to be impractical, administrative controls and procedural requirements SHALL be used to maintain radiation exposures ALARA [10 CFR 835.1001 (b)].

3. The design objective for controlling personnel exposure from external sources of radiation in areas of continuous occupational occupancy $(2000$ hours per year) SHALL be to maintain exposure levels below an average of 0.5 mrem per hour and as far below this average as is reasonably achievable. The design objectives for exposure rates for potential exposure to a radiological worker where occupancy differs from the above SHALL be ALARA and SHALL not exceed 20 percent of the applicable standards listed below from 10 CFR 835 Section 835.202 (10 CFR 835.1002).

- A total effective dose equivalent of 5 rems (0.05 sievert),

- The sum of the deep dose equivalent for external exposures and the committed dose equivalent to any organ or tissue other than the lens of the eye of 50 rems ( 0.5 sievert),

- A lens of the eye dose equivalent of 15 rems ( 0.15 sievert), and

- A shallow dose equivalent of 50 rems (0.5 sievert) to the skin or any extremity.

4. The design of new facilities and modifications to existing facilities are required to incorporate optimization methods to assure that occupational exposure is ALARA (10 CFR 835.1002). (One acceptable optimization method taken from WHC Occupational ALARA Program is described in more detail in Appendix A).

5. The neutron quality factor (at the work area of interest) SHALL be (10 CFR 835.2, quality factor definition):

- for an unknown energy spectrum: $Q_{f}=10$

- for neutrons with known energy less than or equal to $10 \mathrm{keV}: Q_{f}=3$ greater than $10 \mathrm{keV}: \quad Q_{f}=10$ 
- for a known, detailed energy spectrum, as defined below dependent on the energy level:

\begin{tabular}{|c|c|c|c|}
\hline $\begin{array}{c}\text { Neutron } \\
\text { Energy (MeV) }\end{array}$ & $\begin{array}{l}\text { Mean Quali ity } \\
\text { Factor }\end{array}$ & $\begin{array}{c}\text { Neutron } \\
\text { Energy (MeV) }\end{array}$ & $\begin{array}{c}\text { Mean quality } \\
\text { Factor }\end{array}$ \\
\hline $2.5 \times 10^{-8}$ & 2 & 5 & 8 \\
\hline $1 \times 10^{-7}$ & 2 & 7 & 7 \\
\hline $1 \times 10^{-6}$ & 2 & 10 & 6.5 \\
\hline $1 \times 10^{-5}$ & 2 & 14 & 7.5 \\
\hline $1 \times 10^{-4}$ & 2 & 20 & 8 \\
\hline $1 \times 10^{-3}$ & 2 & 40 & 7 \\
\hline $1 \times 10^{-2}$ & 2.5 & 60 & 5.5 \\
\hline $1 \times 10^{-1}$ & 7.5 & $1 \times 10^{2}$ & 4 \\
\hline $5 \times 10^{-1}$ & 11 & $2 \times 10^{2}$ & 3.5 \\
\hline 1 & 11 & $3 \times 10^{2}$ & 3.5 \\
\hline 2.5 & 9 & $4 \times 10^{2}$ & 3.5 \\
\hline
\end{tabular}

a. maximum value in a $30-\mathrm{cm}$ dosimetry phanton.

6. Regarding the control of airborne radioactive material, the design objective SHALL be, under normal conditions, to avoid releases to the workplace atmosphere and in any situation, to control the inhalation of such material by workers to levels that are ALARA; confinement and ventilation SHALL normally be used (10 CFR 835.1002).

7. Actions taken to maintain occupational exposures as low as reasonably achievable, including facility design and control actions required by Sections. 835.1001, 835.1002, and 835.1003, SHALL be documented (10 CFR $835.704)$.

\subsubsection{HSRCM-1 ALARA Design Requirements and Guidance}

\subsubsection{Article 128: Facility Modifications and Radiological Design Considerations}

The following (ALARA requirements and guidance) are provided for new facilities and major modifications to existing facilities:

a. Individual worker dose shall be ALARA, and for new facilities and major modifications to existing facilities SHOULD be less than 500 mrem per year. (Note that approval is expected in March 1996 to change the individual worker dose guidance of less than 500 mrem per year to the 10 CFR 835 requirement of less than $1000 \mathrm{mrem}$ per year, through the Technical Equivalency Determination process of HSRCM-1 Article 113.3).

d. The efficiency of maintenance, decontamination, operations, and decommissioning SHALL be maximized. 
WHC-SD-SNF-SP-010, Rev. 0

e. Components should be (designed and/or) selected to minimize the buildup of (radioactive contamination).

g. Neutron quality factor of 20 for conditions of unknown spectra (or doubling of the neutron quality factor for known neutron energies) SHOULD be used for design purposes. Design analyses based on these neutron quality factors are intended to be used to estimate the additional construction cost that would result if the neutron quality factor was increased. The results of these analyses SHOULD be used to determine the economic feasibility for incorporating such modifications in the final design.

(Designs for the Cold Vacuum Drying module, Hot Conditioning Facility, Canister Storage Building, $K$ Basins Projects, and Fuel Retrieval projects should be based on the neutron quality factors $\left(Q_{\mathrm{f}} s\right)$ listed in item 5 of Section 4.1 .1 , but design optimizations should consider $Q_{\mathrm{f}} s$ that are twice that of item 5 . In general, the occupational dosefrom the design should be reevaluated based on the higher $Q_{f} s$. Design optimizations to reduce the occupational dose should be considered and documented. Those that provide a reduction in dose at a cost-benefit below the monetary value listed in Section 4.2.2 should be included in the design.)

\subsubsection{Article 311: Planning Radiological Work, Requirements}

Technical requirements for the conduct of work, including construction, modifications, operations, maintenance and decommissioning, SHALL incorporate radiological criteria to ensure safety and maintain radiation exposures ALARA. The primary methods used to maintain exposures ALARA SHALL be facility and equipment design features. These features may be augmented by administrative and procedural requirements. To accomplish this, the design and planning processes SHOULD incorporate radiological considerations in the early planning stages. The checklist in Appendix $3 A$ (of HSRCM-1) is helpful in reducing occupational radiation exposure (and is attached in the Appendix to this document).

\subsubsection{Article 312: Planning for Maintenance, Operations and Modifications}

1. Maintenance and modification plans and procedures SHALL be reviewed to identify and incorporate radiological requirements, such as engineering controls and dose and contamination reduction considerations. Performance of this review is the responsibility of 1 ine management, with support and concurrence from the Radiological Control Organization.

3. The Hanford Site trigger levels that shall require formal radiological review of nonroutine or complex work activities are:

- estimated individual or collective dose for a task projected to exceed 1000 person-mrem

- predicted airborne radioactivity concentrations in excess of the DAC (Derived Air Concentration) or an integrated exposure of 200 DAChours

- work in (High Contamination Areas) 
$r$ entry into areas where whole body dose rates exceed $1 \mathrm{rem} / \mathrm{h}$ in a work area

4. Tasks with the potential to exceed the above trigger levels SHALL undergo a formal, documented radiological or ALARA review. At a minimum, this review SHOULD consider the following (design related activities):

b. Elimination or reduction of radioactivity through line flushing and decontamination

c. Use of work processes and special tooling to reduce time in the work area

d. Use of engineered controls to minimize the spread of contamination and generation of airborne radioactivity

f. Use of mock-ups for high exposure or complex tasks

g. Engineering, design and use of temporary shielding to reduce radiation levels

j. Maximization of prefabrication and shop work

$n$. Development of a pre-job estimate of collective dose to be incurred for the job

o. Provisions for waste minimization and disposal.

6. Radiological work anticipated to exceed individual or collective dose criteria established in the HSRCM-1 (7isted in item 312.3 above) SHOULD be reviewed and approved by the ALARA Committee.

7. Optimization techniques, including cost-benefit analysis, represent a fundamental part of radiological design analys is and work review. For review of minor activities with low associated doses, a cost-benefit evaluation is an intrinsic part of the engineering review process and a detailed evaluation is not necessary. For review and planning of major tasks involving higher collective dose expenditures, a detailed and documented evaluation SHALL be performed.

\subsubsection{Article 313: Infrequent or First-Time Activities}

At those facilities with routine, recurring process operations, special management attention SHOULD be directed to radiological activities that are infrequently conducted or represent first-time operations. Planning for such activities SHOULD include:

1. Formal radiological review in accordance with Article 312.4

2. Senior management review directed toward anticipation of concerns and emphas is and specification of protective measures

3. Review and approval by the ALARA Committee

4. Enhanced line and Radiological Control management oversight during the initiation and conduct of the work.

\subsubsection{Articie 316: Minimization of Internal Exposure}

The minimization and control of internal exposure as discussed in Article 136 (of HSRCM-1) SHOULD be conducted in accordance with the following hierarchy of controls: 
WHC-SD-SNF-SP-010, Rev. 0

1. Engineering controls, including containment of radioactive material at the source wherever practicable, SHOULD be the primary method of

minimizing airborne radioactivity and internal exposure to workers.

2. Administrative controls, including access restrictions and the use of specific work practices designed to minimize airborne contamination, SHOULD be used as the secondary method to minimize worker internal exposure.

3. When engineering and administrative controls have been applied and the potential for airborne radioactivity still exists, respiratory protection SHOULD be used to limit internal exposures.

\subsubsection{Article 711: Radiological Records Requirements, Purpose}

Radiological control records SHALL be maintained as necessary to document compliance with the requirements of 10 CFR 835.

\subsubsection{SNF Project ALARA Design Requirements and Guidance}

1. The source term that shall be used for radiological evaluations with:

spent nuclear fuel and sludge is identified in 105-K Basin Material Design Basis Feed Description for Spent Nuclear Fuel Project

Facilities (Willis 1996). The radionuclide inventory of the spent nuclear fuel with the maximum dose consequence is identified in Table 3.8, while that with the average dose consequence is identified in Tables 2.4 and 3.5. The spent nuclear fuel source term is consistent with the nuclear material accountability records.

$K$ Basin pool water beginning with the SNF and sludge removal period, will be identified in. Functional Design Criteria For The $K$ East Basin Integrated Water System (WHC 1996). The draft of this document is currently being reviewed.

2. Estimates of $K$ Basin background dose rates, being developed by $K$ Basins Projects, should be used for radiological evaluations when they are made available through a Supporting Document.

\subsection{Design Optimization for ALARA}

The design of new facilities and modifications to existing facilities are required to incorporate optimization methods to assure that occupational exposure is ALARA (10 CFR 835.1002). Subproject managers, design authorities, and design agents have responsibility to ensure that optimization methods are included in designs.

\subsubsection{Level of Effort}

The level of effort involved in documenting ALARA decisions should be commensurate with the costs and potential dose savings to be realized. Detailed optimization evaluations shall be made to support ALARA decisions, unless their cost, together with the cost of documentation, outweigh the potential value of the benefits. The HSRCM-1 trigger levels on which design activities for new facilities and modifications to existing facilities should 
undergo formal ALARA review are listed in item 3 of Section 4.1.2.3 of this document. The methodology used to determine which dose reduction and contamination minimization efforts are reasonable involves judgements to evaluate the "appropriateness" of ALARA protective measures based on the relative value of social, technical, and economic factors (G-10 CFR 835-IVH).

\subsubsection{Methodology}

No particular optimization methodology is mandated. However, the methodology chosen should directly compare the dose and cost impacts using a monetary value for a person-rem, in addition to it resulting in consistent, rational, documentable, coherent decisions as to which dose reduction efforts are reasonable. One acceptable methodology is described in Appendix A (WHC 1995). A copy of the ALARA optimization evaluations shall be included in. the design records and a copy shall be sent to the WHC ALARA Program Office (WHC 1995).

The monetary value of collective dose that shall be used in ALARA optimizations and in neutron quality factor impact calculations (of Section 4.1.2.1, item g) is currently set at $\$ 30,000 /$ person-rem (Wiemers 1995).

\subsection{ALARA Design Review}

Design reviews are required to ensure that the appropriate radiological design criteria and practices are incorporated into modifications of existing facilities and designs of new facilities early in the engineering and design process (WHC 1995, G-10 CFR 835). The purpose of the reviews is to verify that sound radiological considerations such as dose reduction and contamination minimization considerations are integrated into the design, construction procedures, proposed operating procedures, and decommissioning plans. The ALARA reviews should begin as early as the development of functions and requirements, but no later than the conceptual design stage, and be included in each of the subsequent major design reviews. The reviews should involve experienced radiological control personnel. These radiological design reviews can be a part of the normal project design reviews.

Designs for activities that occur in the $K$ Basins, must have separate review and approval by the $K$ Basin ALARA Committee prior to startup. (The $K$ Basins ALARA Committee is a multi-disciplined committee comprised of personnel from various major functions at the $K$ Basins). Periodic review by the $K$ Basin ALARA Committee throughout the design stage can be very beneficial and should be considered, but is not mandatory. New facilities, e.g., CVD, CSB and HVC, must undergo appropriate ALARA review by a facility ALARA committee prior to startup; however ALARA Committees for these facilities have not been established yet.

Additional design review assistance, outside of most subprojects, is available through the $K$ Basins Projects ALARA support team. The team members have a wide range of government and commercial nuclear experiences. Many of the members are also on the $K$ Bas in ALARA Committee. The $K$ Basins Projects ALARA support team was specifically set up and staffed, as an informal temporary group, to ass ist the $K$ Basins Projects subproject, however they can provide 1 imited assistance to other SNF Project subprojects, if requested. The $K$ Basins Projects ALARA support team can be reached through the $K$ Basin Projects organization. 
An ALARA design review process is identified in WHC Occupational ALARA Program (WHC 1995). It consists of the six phases 1 isted below, although their order of completion may be varied to better suit the review:

- conduct a dose assessment;

- review radiological design conditions against established trigger levels;

- identify the applicable radiological design criteria;

- select alternatives by using approved optimization methods;

- in the design package, incorporate and document features to reduce the dose and the spread of radioactive materials; and

- review previous jobs, designs, and processes that have similar hazards.

A companion ALARA Design Review checklist, that can assist in performing design reviews involving new or modified facilities, is available as Macro WEF042 and is included in Appendix A. Other review processes are also acceptable, provided they verify and document that sound radiological considerations such as dose reduction and contamination minimization considerations are integrated into the design, construction procedures, proposed operating procedures, and decommissioning plans. An ALARA design review checklist, similar to that in Appendix $A$, shall be completed as part of the ALARA design review. A copy of the ALARA design review checklists shall be included in the design records and a copy shall be sent to the WHC ALARA Program office (WHC 1995).

Subproject managers should approve the results of the ALARA design review, including the dose assessment, considerations and criteria review, cost-benefit records, and recommendations for reductions, while design authorities should ensure that the design package includes all of the records and reviews (WHC 1995). Dose assessments for the subproject activities will be tracked and reported as described in Section 5.2 below.

\subsection{Overal1 Project Dose Management}

Careful management and reduction of the occupational dose will be required for successful project completion, since the initial estimates of dose were high (Bergman 1995 and Scott 1995). This is primarily due to the background dose in KE Basin and the limited crane capacity for cask lifts. Subsequent analyses reaffirm this management need (Parsons 1995, Eacker 1995, and Voyles 1996).

The ALARA analyses and design reviews described in Section 4 not sufficiently reduce occupational dose by themselves. The two primary reasons are:

- $\quad$ ALARA analyses and design reviews focus on activities within a particular subproject and multiple subprojects will be conducting activities both concurrently and in adjacent or overlapping physical areas. The 
WHC-SD-SNF-SP-010, Rev. 0

occupational exposure caused by the background dose from one subproject on another may not be readily apparent to the causative subproject.

Further complicating the analyses and design optimizations is that there are two sources of background dose; the high static background dose from the existing $K$ Basin source terms and the dynamic background dose from one or more adjacent subprojects involved with SNF removal, sludge removal, debris removal, and water treatment activities. Reducing the static background dose is the responsibility of $\mathrm{K}$ Basins Projects, while reducing the dynamic background dose is the responsibility of the causative SNF fuel, sludge, debris, water, etc. subproject(s).

- it is inefficient to increase staff more than absolutely necessary for such a short operating period, due to the lower productivity of the new personnel on unfamiliar tasks and the need to divert experienced personnel to the training and supervision of the new personnel. This may require that dose reduction steps be taken beyond those supported by the current monetary value assigned to dose in Section 4.2.2.

As a result, additional direction from the SNF Project management will be provided to completely manage SNF Project and subproject doses.

\subsection{Dose Management Team}

To provide the required overall direction, a dose management team will routinely review the dose estimates for the subprojects and provide any necessary direction to the subproject managers for additional dose reduction efforts. This small team will include the Manager of Integration and the Fuel Handling Operations Manager, with support from an experienced radiological control engineer and representatives from SNF Project Engineering Support.

To assist the Dose Management Team (DMT), the estimated dose for the project, each subproject, and the subproject tasks will be routinely updated using the calculational models that have evolved in the earlier studies, most recently described in Eacker 1995 and Voyles 1996. The models for each subtask will be updated, as information on the processing steps, staffing requirements and radiation fields are refined. The interaction of subprojects will be included through the radiation field and task duration estimates.

Dose reduction efforts will be prioritized using two primary tools. The first is hierarchical lists of task doses compiled for the complete project and for each subproject. These lists will be generated by the calculational model and will be easily updated. They will highlight the areas of greatest opportunity for SNF Project dose reduction.

The second is a dose budget and hierarchical 1 ist of dose-reducing, potential design changes for each subproject. The following sequence is representative of the process that will be used.

1. The DMT will identify an initial dose target for each subproject.

2. The subproject managers will identify sufficient potential design changes and the associated dose reduction, cost and schedule impacts, to meet their assigned target. 
WHC-SD-SNF-SP-010, Rev. 0

3. The DMT will review the potential design changes, considering cost benefit and schedule impacts.

4. The dose targets of some subprojects could be revised by the DMT to balance the impacts between subprojects (requiring the subproject managers to identify additional design changes) or could require a subproject to evaluate the result of reducing an indirect impact on another subproject.

5. The DMT, with concurrence from Senior Management and input from the affected subproject managers, will select the dose reduction requirement for each subproject and the design changes to be implemented, based on total Project needs. Significant revisions to a subproject scope could require updates of the dose reduction requirements of several subprojects.

\subsection{Dose Management Performance Indicators}

The performance indicators for dose management during the design activities are the estimated occupational doses for the total project and each subproject. The estimated doses will be tracked over the subprojects design periods. The estimated doses will be reported in a supporting document, that will be issued quarterly or after changes to subproject designs that significantly impact dose. The dose estimates will also be included on the process flow diagrams for the SNF Project.

\subsection{GLOSSARY}

Administrative Control Level - A numerical dose constraint established at a level below the regulatory limit to administratively control and help reduce individual and collective radiation exposure.

As Low As Reasonably Achievable (ALARA) - The approach to radiation protection is to maintain and control individual and collective exposures to the work force and general public to levels as low as is reasonable. This approach considers social, technical, economic, practical, and public policy needs. ALARA is not a dose limit, it is a process to achieve and maintain dose and contamination reduction within acceptable limits and as far below these limits as is reasonably achievable.

cost-benefit-analysis - An analysis and comparison of the dollar cost of a protective measure versus the benefit derived from that protective measure. This document is completed by the project engineer with assistance, if requested, from the ALARA committee chairperson and Radiological Engineering. It is reviewed by the ALARA committee chairperson. A copy of the analysis should be sent to the ALARA committee chairman for distribution.

dose - The amount of energy deposited in body tissue due to radiation exposure. Various technical terms, such as dose equivalent, effective dose equivalent and collective dose, are used to evaluate the amount of radiation an exposed worker receives. These terms are used to describe the differing interactions of radiation with tissue as well as to assist in the management of personnel exposure to radiation. 
absorbed dose (D) - energy absorbed by matter from ionizing radiation per unit mass of irradiated material at the place of interest in that material. The absorbed dose is expressed in units of rad (or gray) ( $1 \mathrm{rad}=0.01$ gray).

committed dose equivalent $\left(H_{T, 50}\right) \rightarrow$ the dose equivalent calculated to be received by a tissue or organ over a 50-year period after the intake of a radionuclide into the body. It does not include contributions from radiation sources external to the body. Committed dose equivalent is expressed in units of rem (or sievert).

committed effective dose equivalent $\left(H_{E, 50}\right)$ - the sum of the committed dose equivalents to various tissues in the body $\left(H_{T, 50}\right)$, each multiplied by the appropriate weighting factor $\left(W_{T}\right)$, that is $H_{E, 50}=\Sigma W_{T} H_{T}, 50$. The effective dose equivalent is expressed in units of rem (or siévert).

deep dose equivalent - the dose equivalent derived from external radiation at a tissue depth of $1 \mathrm{~cm}$ in tissue.

dose equivalent $\left(H_{T}\right)$ - the product of the absorbed dose (D) (in rad or gray) in tissue, a quality factor $(Q)$ and all other modifying factors (N). Dose equivalent is expressed in units of rem (or sievert). (1 rem = 0.01 sievert).

effective dose equivalent $\left(H_{E}\right)$ - the summation of the products of the dose equivalent received by specified tissues of the body $\left(H_{T}\right)$ and the appropriate weighting factors $\left(W_{T}\right)$, that is $\left(H_{E}=\Sigma W_{T} H_{T}\right)$. It includes the dose from radiation sources internal and/or external to the body. The effective dose equivalent is expressed in units of rem (or sievert).

external dose or exposure - that portion of the dose equivalent received from radiation sources outside the body (e.g., "external sources").

gray (Gy) - SI unit of absorbed dose. Qne gray is equal to an absorbed dose of 1 joule per kilogram. (100 rads).

internal dose or exposure - that portion of the dose equivalent received from radioactive material taken into the body (e.g., "internal sources").

quality factor - the principal modifying factor used to calculate the dose equivalent from the absorbed dose; the absorbed dose (expressed in rad or gray is multiplied by the appropriate quality factor (Q).

rad - unit of absorbed dose. One rad is equal to an absorbed dose of 100 ergs per gram or 0.01 joules per kilogram (0.01 gray).

rem - unit of dose equivalent. Dose equivalent in rem is numerically equal to the absorbed dose in rad multiplied by a quality factor, distribution factor, and any other necessary modifying factor (1 rem = 0.01 sievert).

sievert (SV) - unit of any of the quantities expressed as dose equivalent. The dose equivalent in sieverts is equal to the absorbed dose in grays multiplied by the quality factor ( $1 \mathrm{~Sv}=100$ rems). 
total effective dose equivalent (TEDE) - the sum of the effective dose equivalent (for external exposures) and the committed effective dose equivalent (for internal exposures). Deep dose equivalent to the whole body may be used as effective dose equivalent for external exposures.

weighting factor $\left(W_{T}\right)$ - the fraction of the overall health risk, resulting from uniform, whole body irradiation, attributable to specific tissue. The dose equivalent to the affected $t$ issue, $H_{T}$, is multiplied by the appropriate weighting factor to obtain the effective dose equivalent contribution from that $t$ issue.

whole body - for the purposes of external exposure, head, trunk (including male gonads), arms above and including the elbow, or legs above and including the knee.

whole body dose - the sum of the annual deep dose equivalent for external exposures and the committed effective dose equivalent for internal exposures.

facility - systems, buildings, utilities, and related activities whose use is directed to a common purpose at a single location.

optimization - The process of making something, such as a design, system, or operational practice as perfect, functional, or effective as possible. The optimal level of radiation protection for a particular work practice depends on many factors including cost, reduction in risk, and the detriment associated with the dose.

radiation or ionizing radiation - alpha particles, beta particles, gamma rays, X-rays, neutrons, high-speed electrons, high-speed photons, and other particles capable of producing ions. 
WHC-SD-SNF-SP-010, Rev. 0

\subsection{REFERENCES}

10 CFR 835, Occupational Radiation Protection, Code of Federal Regulations, as amended.

DOE, 1988, Radioactive Waste Management, DOE Order 5820.2A, U.S. Department of Energy, Washington D. C.

DOE, 1989, General Design Criteria, DOE Order 6430.1A, U.S. Department of Energy, Washington D. C.

DOE, 1990, Radiation Protection of the Public and the Environment, DOE Order 5400.5, U.S. Department of Energy, Washington D. C.

DOE, 1994, Radiation Contro7 Manual, DOE \EH-0256T, Rev. 1, U.S. Department of Energy, Washington D. C.

G-10 CFR 835, Implementation Guide For Use With Title 10, Code of Federal Regulations, Part 835, Occupational Radiation Protection, G-10 CFR 835/B2, Rev. 0, .S. Department of Energy, Washington D.C.

Bergman, T. B, 1995, K Basin Path Forward Dose Estimates, EDT 160163, West inghouse Hanford Company, Richland, Washington.

Eacker, J. A., 1995, $K$ Basin Dose and Staffing Management Project Final Report, (letter to W. J. Millsap, ICF Kaiser Hanford Company, September 18), RUST Federal Services, Richland, Washington,

Evans, R. A., 1994, Radiological Design Guide, WHC-SD-GN-DGS-30011, Rev. 0, Westinghouse Hanford Company, Richland; Washington.

HSRCM-1, Hanford Site Radiological Control Manual, HSRCM-1, Rev. 2, U.S. Department of Energy, Richland Operations Office, Richland, Washington.

Parsons, 1995, Trade Study for K Basin Spent Nuclear Fuel Removal and Conditioning, August 11, Parsons Engineering Science, Inc., Richland, Washington,

PNL, 1988, Health Physics Manual of Good Practices for Reducing Radiation Exposure to Levels that are As Low As Reasonably Achievable (ALARA), PNL-6577, Pacific Northwest Laboratory, Richland, Washington.

Scott, D. W., 1995, Initial Time-Motion-Dose Study for $K$ Basin Fuel Removal, (letter to A. T. Kee, West inghouse Hanford Company, March 29), Los Alamos Technical Associates, Inc., Richland, Washington.

Voyles, G. S., 1996, Spent Nuclear Fuel Project, Initial Project Dose and Resource Assessment, WHC-SD-SNF-TA-008, Rev. 0, West inghouse Hanford Company, Richland, Washington.

WHC, 1995, WHC Occupational ALARA Program, WHC-IP-1043, Rev. 0, Westinghouse Hanford Company, Richland, Washington. 
WHC, 1996, Functional Design Criteria For The $K$ East Basin Integrated Water System, WHC-SD-SNF-FDC-002, Draft, Westinghouse Hanford Company, Richland, Washington.

Wiemers, M. J., 1995, Monetary Value of Collective Dose, (internal memorandum to D. W. Siddoway, November 3,), Westinghouse Hanford Company, Richland, Washington.

Will is, W. L., 1996, 105-K Basin Material Design Basis Feed Description for Spent Nuclear Fuel Project Facilities, WHC-SD-SNF-TI-009, Rev. OA, Westinghouse Hanford Company, Richland, Washington. 
WHC-SD-SNF-SP-010, Rev. 0

APPENDIX A. ALARA Optimization and Design Review Forms 
WHC-SD-SNF-SP-010, Rev. 0

This page intentionally left blank 


\begin{tabular}{llr} 
WHC-SD-SNF-SP-010, Rev. 0 & & \\
WHC-IP-1043, WHC Occupational ALARA Program & Section: & 8.0 \\
& Revision: & 0 \\
Optimization Methodology & Date: & $06 / 30 / 95$ \\
\hline
\end{tabular}

\section{APPENDIX A \\ WESTINGHOUSE HANFORD COMPANY OPTIMIZATION METHODOLOGY (Cost/Benefit Analysis)}

The policy of the DOE is to operate its facilities and conduct its research to maintain radiation exposures as far below the prescribed limits as is reasonably achievable. Optimization is the process of making something, such as a design, system, or oper_tional practice as perfect, functional, or effective as possible. ICRP-55 states that "...optimization provides a basic framework of thinking wherein it is proper to carry out some kind of balancing of the resources put into production, and the level of protection obtained against a background of other factors and constraints, so as to obtain the best that can be achieved in the circumstances." ALARA is synonymously defined in DOE/EH-0256T as "An approach to radiological control to manage and control exposures (both individual and collective) to the work force and general public at levels as low as reasonable, taking into account social, technical, economic, practical, and public policy considerations. As used in this Order, ALARA is not a dose limit but a process, which has the objective of attaining doses as far below the applicable controlling limits as is reasonably achievable."

To determine if alternatives will reduce dose and the spread of radioactive contamination to as low as is reasonably achievable, a quantitative method or decision-making techniques should be employed. DOE/EH-0256T requires that design objectives use the optimization principles, such as those discussed in ICRP-37 when justifying changes in facility design to control occupational exposure. ICRP-55 also provides relevant guidance on optimization and the decision-making process. DOE 5400.5 requires that "...contractors develop a program to implement the ALARA process for all activities that cause dose to the general public." Furthermore, DOE 5400.5 states that "...Factors to be considered, at the minimum, shall include:

1. The maximum dose to the public,

2. The collective dose to the population,

3. Alternative methods of processing, treating, controlling, and operating radioactive effluent systems,

4. The dose associated with each alternative,

5. The cost for each technological alternative,

6. Examination of the changes in costs associated with the various alternatives, and

7. Examination of the changes in societal impact associated with the various alternatives."

In addition, PNL-6577 states that the following minimum steps are needed for cost/benefit analysis to optimize dose reduction:

"1. Identify all possible options...

2. For each option, determine both the individual and collective dose equivalent that will result...

3. For each viable option, identify all associated costs and determine the net cost for each option by summing the identified costs...

4. Determine the cost equivalent of the doses resulting from each option...

5. Sum the costs identified in Steps (3) and (4) to determine the total net cost for each option... 
WHC-SD-SNF-SP-010, Rev. 0

WHC-IP-1043, WHC Occupational ALARA Program

Section:

6. The option with the lowest total net cost is the optimal option...

7. A sensitivity analysis should be performed to determine how the solution depends on the assumptions that are required to perform the optimization analysis..."

During the initial stages of the conceptual design and throughout the design phase, but prior to the final selection of the applicable ALARA design consideration, it may be necessary for the cognizant engineer or his designated alternate to perform a cost/benefit analysis. Those changes to the design for which costs do not have an obvious justification and which significantly increase the total project's cost should have a quantitative cost/benefit periurmed.

The cost/benefit analysis involves estimating the net costs and net benefits associated with the design change. These costs and savings must be estimated over the life of the new technique. In addition, if adjustment of costs or savings. is needed to correct inflation, then Future Value Factors can be used to update estimates from the past to the base year.

The costs from the new technique which may require estimation are:

- Engineering Costs

- Installation Labor Costs

- Capitol Equipment, Fabrication, and Materials Costs

- Training, Procedures, Operating, and Maintenance Costs

- Chemical Costs

- New Tool Costs

- Consumable Costs

- Dose Increase Costs

The benefits for the new techniques which may require estimation are:

- Maintenance Savings

- Operations Savings

- Surveillance/Inspection Savings

- Replacement Power Savings

- Improved Efficiency and Reliability Savings

- Radwaste Savings

- Salvage Savings

- Decreased Usage of Chemical and Consumable Material Savings

- Dose Savings

The dose increase and savings in person-rem can be converted to dollars using a lower limit value of $\mathbf{\$ 2 , 0 0 0}$ or an upper limit value of $\$ 10,000$ per person-rem (DOE EH-0277-T). This will allow these costs and savings to be added to the other cost and savings to determine if the net dollars is a cost or a benefit.

A summary of the description and results of any cost benefit to be performed should be documented on the cost benefit analysis worksheets (see Figures 8-2 through 8-9). The inclusion of the completed cost benefit analysis worksheet to the work package is optional. 
WHC-SD-SNF-SP-010, Rev. 0

WHC-IP-1043, WHC Occrpational ALARA Program

Section:

Revision:

Date:

There are four major steps to this cost/benefit methodology:

1. Define the radiological problem

2. Perform the overriding factor analysis.

3. Calculate the net benefit.

4. Perform the ALARA factor analysis.

The types of data that will be needed to define the problem are a written description of the radiological problem, a description of the alternatives for ALARA protective meisures (APM), the time frame for which the protective measure will be used, the savings, the costs, and the estimates for collective and maximum individual dose. See Figure 8-1 for a flow chart of the ALARA protective measure analysis process, and Figure $8-2$ for a worksheet that can be used to define radiological problems.

After the problem is defined and the data collected, an overriding factor analysis is performed. This involves asking such questions as:

- Will a violation of a DOE Order, federal regulation, or state law occur?

- Will a violation of a collective bargaining agreement be generated by the activity?

- Will significant quantities of radioactive material be added to the site?

- Will administrative dose control level(s) be exceeded?

- Will a safety related activity not be completed because a specially trained, skilled, or certified worker is unavailable?

- Will an unsafe condition that could lead to worker injury be created?

These questions are answered yes or no for each scenario: an APM should be implemented or an APM should not be implemented (see Figure 8-3). If there are overriding criteria against implementing the APM, then it is not justified. Conversely, if there are overriding criteria for implementing the APM, then it is justified regardless of the costs or benefits.

Next, the net benefit analysis will be performed. First, calculate the marginal or differential economic benefits, including such benefits as maintenance labor savings, operational/production savings, inspection/surveillance savings, process efficiency/reliability savings, as well as other miscellaneous saving (see Figure 8-4). Second, calculate the marginal potential costs, such as those costs associated with design and engineering; materials, equipment, and fabrication; installation/construction; training and procedures; operating and maintenance; as well as other miscellaneous costs, e.g., chemicals, consumables, special tools, and radwaste disposal (see Figure 8-5). Third, calculate net dose savings. This equates to the dose associated with the existing radiological activity minus the dose with the APM implemented and the dose to implement the APM (see Figure 8-6):

Next, evaluate whether or not the net benefits are positive. To obtain the net benefit, subtract the estimated economic costs (Box D in Figure 8-5) from the estimated economic benefits (Box C in Figure $8-4$ ). In addition, add the benefits to be accrued by the dose savings to the net benefit. To do this convert the net dose savings (Box $\mathrm{E}$ in Figure 8-6) to its equivalent dollar value. For this exercise, a two-tiered detriment value system will be used which is based on a study on the evaluation of a unit of dose performed by Brookhaven National Laboratory (DOE EH-0277T). 
WHC-SD-SNF-SP-010, Rev. 0

WHC-IP-1043, WHC Ocqunational ALARA Program

Section:

Revision:

Date:

This methodology is based on the estimated dose to the maximum individual without the protective measure. A value of $\mathbf{\$ 2 , 0 0 0}$ per person-rem is suggested as a nominal value for low dose operations where the maximum individual is estimated to receive a dose less than $1 \mathrm{rem} / \mathrm{yr}$. An upper level value for dose detriment of $\$ 10,000$ per person-rem will be used for those high dose activities where the maximum individual is estimated to receive a dose equal to or greater than $1 \mathrm{rem} / \mathrm{yr}$.

If, after adding the benefit of net dose savings expressed in dollars, for the lower level detriment value of $\$ \mathbf{2 , 0 0 0}$ to the previously calculated economic net benefit (see Figure 8-7), the net benefit is greater than zero, then the protective measure is justified. If it is not, $t^{\circ}$ en an ALARA factor analysis should be performed (see Figure 8-9). If the upper level net benefit evaluation, i.e., $\$ 10,000 /$ personrem, are not less than zero, then an ALARA factor analysis should be performed (see Figure 8-9). If the net benefits are less than zero, then the measure is not justified. At this point a case-specific evaluation could be performed to determine if assignment of a radiation detriment value of greater than $\$ 10,000$ per person-rem is warranted. This could result in the measure being justified.

Finally, for those situations in which an ALARA factor analysis will be required, answer yes or no to the questions that deal with qualitative factors and enter the value of the corresponding weighing factor into either the yes or no box. If, after tallying these weighing factors, the yes total is greater than that for the no answers, the APM should be accepted based on qualitative factors. If the no answer total outweighs that for the yes answers, or if they are equal, the APM should be rejected or accepted based on other factors.

Appendix B provides an example of how to apply data shown in Figures 8-2 through 8-9 in a costbenefit analysis. A worksheet format is used in Appendix $\mathbf{B}$ to help clarify the example given. 
WHC-SD-SNF-SP-010, Rev. 0

WHC-IP-1043, WHC Occupational ALARA Program

Section:

Revision:

Date:

Page:

Figure 8-1. ALARA Protective Measure Analysis - Flow Chart.

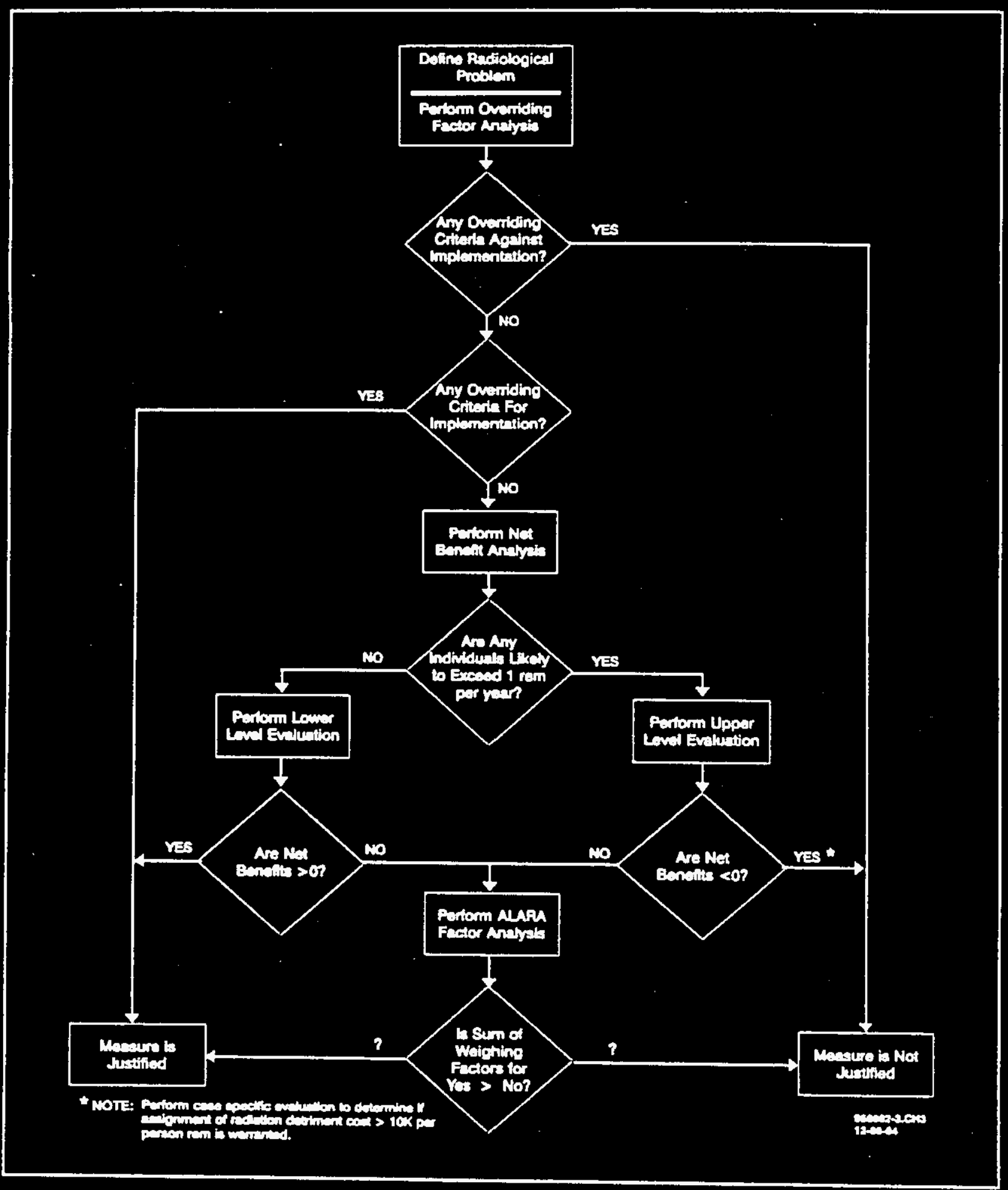


WHC-SD-SNF-SP-010, Rev. 0

$\begin{array}{llr}\text { WHC-IP-1043, WHC Occupational ALARA Program } & \text { Section: } & 8.0 \\ & \text { Revision: } & 0 \\ \text { Optimization Methodology } & \text { Date: } & 06 / 30 / 95 \\ & \text { Page: } & 8 \text { of } 24\end{array}$

Figure 8-2. Radiological Problem Definition.

1. Describe the facility, its present radiological conditions, and the radiological activity of concern.

2. Describe the proposed ALARA protective measure (APM).

3. Determine the relevant time frame (for estimation of cost elements and exposure impacts) for which the protective measure will be used.

4. Identify the cost anvings ascociated with the implementation of the APM (e.8., maintenance labor, operations labor, inspection labor, production, processing, salvage, reduced chemicals, reduced consumables, reduced radwasto).

5. Identify the cost elements for implementation of the APM (e.g., design and engineering, equipment procurement, fabrication, installation or construction labor, operation, mintenance, sssociated training and procedure, additional chemicals, additional consumables, special tools, additional radwaste).

6. Estimate the collective dose (1) without the protective measure, (2) with the protective measure, and (3) to implement the protective measure. Determine, if possible, the maximum individual dose for the present or existing radiological activity. 
Figure 8-3. Overriding Factor Analysis.

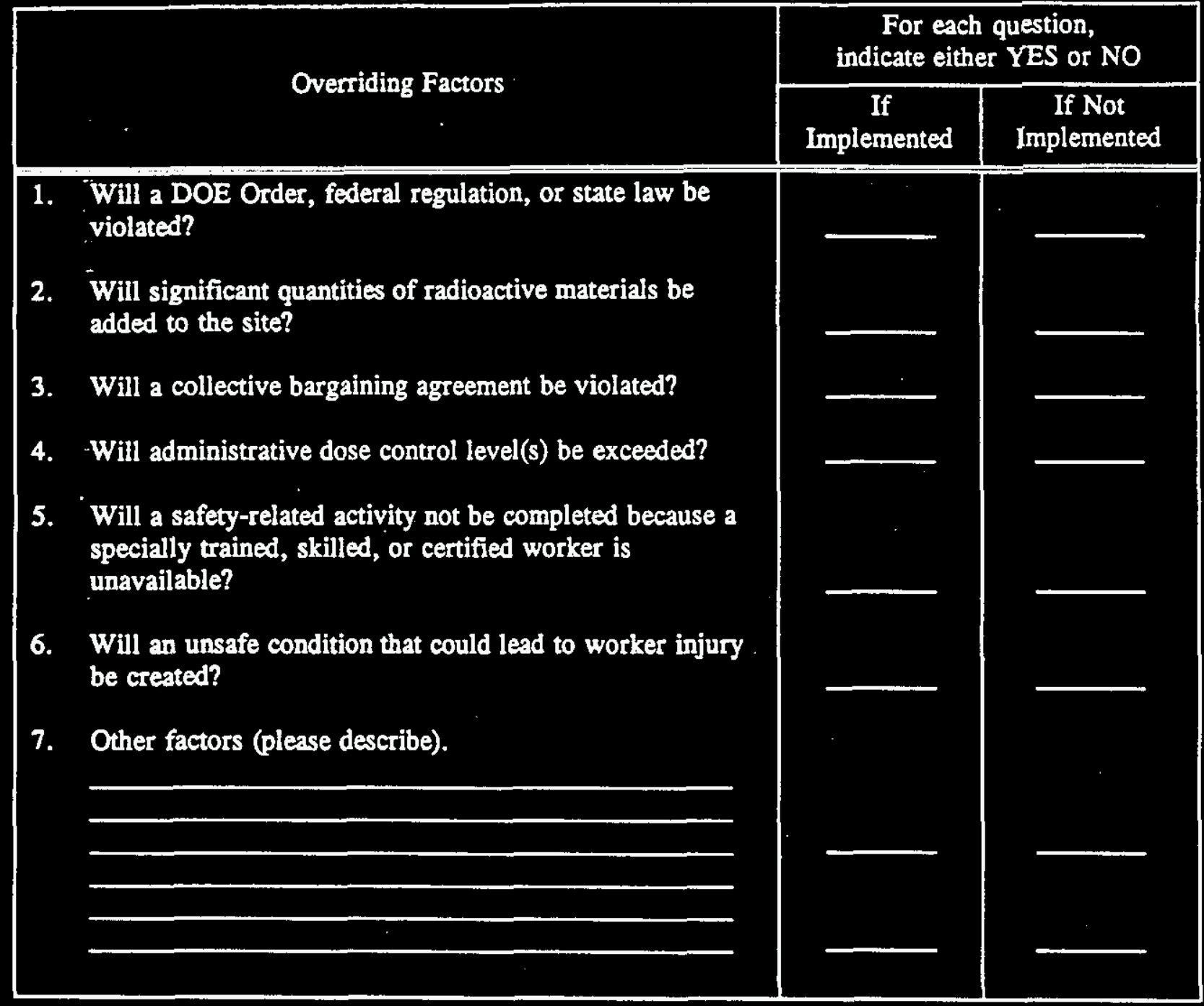

8. Conclusion (explain how YES answers to the above questions are overriding factors).

9. Discussion (basis and references). 
WHC-SD-SNF-SP-010, Rev. 0

WHC-IP-1043, WHC Oceupational ALARA Program

Section:

Revision:

Date:

Optimization Methodology

Page:

Figure 8-4. ALARA Protective Measure Benefit Calculation.

\begin{tabular}{|c|c|c|c|c|}
\hline Benefits & Quantity & $\begin{array}{l}\text { Unit } \\
\text { Cost }\end{array}$ & Cost & $\operatorname{Item}(s)$ \\
\hline $\begin{array}{l}\text { C-1 Maintenance Labor } \\
\text { Enter the total estimated labor savings for the protective } \\
\text { mensure. Obtain the estimated total maintenance hours saved. } \\
\text { Obtain the approprinte dollar/hour rate for maintenance. } \\
\text { Enter the product(s) on line(s) for items C-1. }\end{array}$ & & & & C-1 \\
\hline $\begin{array}{l}\text { C-2 Operations/Production Labor } \\
\text { Enter the total estimated operation/production labor savings } \\
\text { for the protective measure. Obtain the estimated total } \\
\text { operation hours saved. Obtain the approprinte dollar/hour } \\
\text { rate for operations. Enter the produet(s) on line(s) for } \\
\text { items C-2. }\end{array}$ & & & & $C-2$ \\
\hline $\begin{array}{l}\text { C-3 Inspection/Surveillance Labor } \\
\text { Enter the total estimated inspection/surveillance labor anvings } \\
\text { for the protective measure. Obtain the estimnted total } \\
\text { operation hours saved. Obtain the appropriate dollar/hour } \\
\text { nte for inspection. Enter the product(8) on line(s) for } \\
\text { items C-3. }\end{array}$ & & & & C.3 \\
\hline $\begin{array}{l}\text { C-4 Efficiency and/or Reliability Savings } \\
\text { Enter the total estimated savings associated with production or } \\
\text { processing improvements provided by the protective measure. } \\
\text { Enter the dollar amount of these savings on line(s) for } \\
\text { items C-4. }\end{array}$ & & & & $C-4$ \\
\hline $\begin{array}{l}\text { C-5 Miscellaneous Savings } \\
\text { Enter estimated savings from miscellaneous items (e.g., } \\
\text { salvage value of old equipment, reduced chemical and } \\
\text { consumable materials, reduced redwaste). Enter the dollar } \\
\text { amount of these savings on line(s) for items C-5. }\end{array}$ & & & & C-5 \\
\hline
\end{tabular}

TOTAL ECONOMIC BENEFTSS

Enter the total estimated benefits of the protective measure. Add all savings from lines for items C-1 through C.5, and enter total into Box C. 
Figure 8-5. ALARA Protective Measure Cost Calculation.

\begin{tabular}{|c|c|c|c|c|}
\hline Benefits & Quantity & $\begin{array}{l}\text { Uait } \\
\text { Cost }\end{array}$ & Cost & Irem(s) \\
\hline $\begin{array}{l}\text { D-1 Design and Engineering } \\
\text { Enter the total eatimated design engineering cost for the } \\
\text { protective measure. Obtain the estimated hours to design and } \\
\text { engineer the productive measure. Obtain appropriate dollar/hour } \\
\text { rate for engineering. Enter the; roduet(s) on line(s) for } \\
\text { items D-1. }\end{array}$ & & & & D-1 \\
\hline $\begin{array}{l}\text { D-2 Capital Equipment, Fabrication, Material } \\
\text { Enter the total estimated capital costs of equipment, fabrication, } \\
\text { and materials for the new technique. Include "up front" hidden } \\
\text { costs much as R\&D, certification, patent rights, etc. Enter } \\
\text { produet(s) on line(s) for items D-2. }\end{array}$ & & & & D-2 \\
\hline $\begin{array}{l}\text { D-3 Installation or Construction } \\
\text { Enter the total estimated labor costs to install the protective } \\
\text { measure. Obtain the estimated total hours of station and } \\
\text { contractor perronnel to install. Obtain the appropriate } \\
\text { dollar/hour rate for station and contractor labor. Enter the } \\
\text { product(o) on line(o) for items D-3. }\end{array}$ & & & & D-3 \\
\hline $\begin{array}{l}\text { D-4 Implementation: Procedure, Training, } \\
\text { Administrative Costs } \\
\text { Enter the estimated costs for training, procedure development, } \\
\text { and associated additional O\&M protective measure (additional } \\
\text { O\&M being a negative savings obtained in lines C-1, C-2, and } \\
\text { C-3 above from the difference between the existing and the } \\
\text { protective technique costs for operations, maintenance, and } \\
\text { inspection). Enter the product(s) on line(s) for items D-4. }\end{array}$ & & & & D-4 \\
\hline $\begin{array}{l}\text { D-5 Operation and Maintenance } \\
\text { Enter the total estimated cost to operate and mainkain the } \\
\text { protective measure. Obtain the estimated hours to maintain and } \\
\text { operate. Obtain the appropriate dollar/hour rate for each work } \\
\text { group. Enter the product(8) on line(s) for items D-5. }\end{array}$ & & & & D-5 \\
\hline $\begin{array}{l}\text { D-6 Miscellaneous Costs } \\
\text { Enter the estimated total costs for miscellaneous items (e.8., } \\
\text { chemicals, consumable materials, special tools, additional } \\
\text { radwaste). Enter the product(s) on line(s) for item(s) D-6, }\end{array}$ & & & & D-6 \\
\hline
\end{tabular}

\section{TOTAL ECONOMC COSTS}

Enter the total estimated costs of the protective mearure. Add all the costs from lines for items D-1 through D-6 and enter total into Box D. 
WHC-SD-SNF-SP-010, Rev. 0

WHC-IP-1043, WHC Occunational ALARA Program

Section:

Revision:

-

Date:

Optimization Methodology

Page:

Figure 8-6. Dose Estimate.

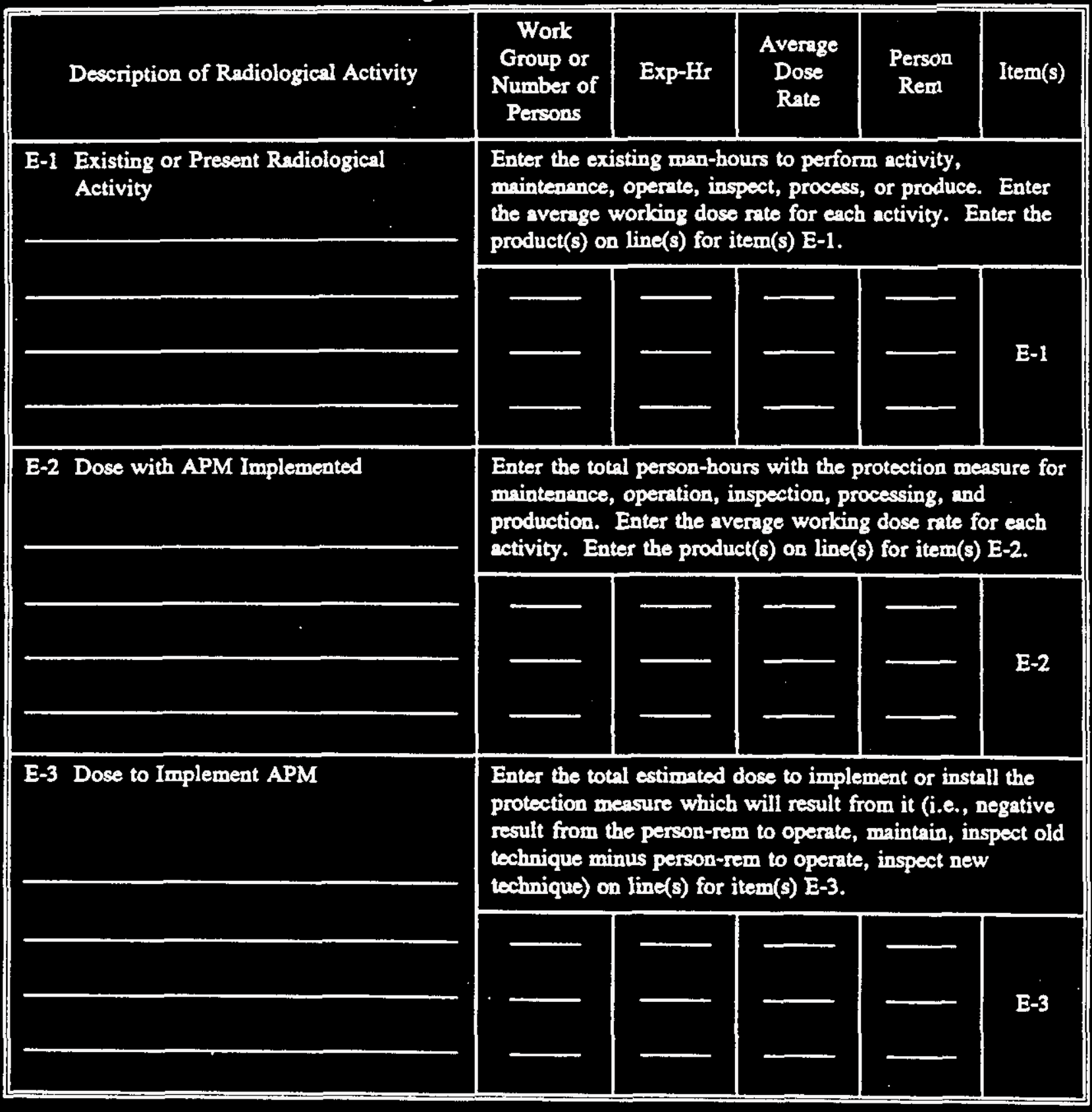

NET DOSE SAVINGS

Enter total estimated dose saved for the protective measure (i.e., positive results from the person-rem to operate, maintain, inspect old technique minus person-rem to operate, maintain, inspect with protective measure plus the dose to implement the APM) in Box E.

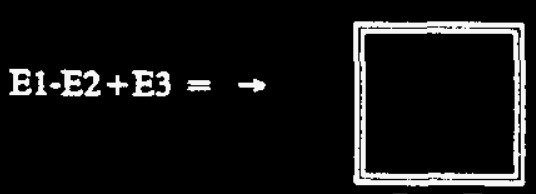

Box E 
Figure 8-7. Lower-Level Net Benefit Evaluation.

\begin{tabular}{|l|l|c|}
\hline \multicolumn{1}{|c|}{ Cost/Benefit } & Dollars & Item(s) \\
\hline F-1 Estimated Economic Benefits & & \\
Enter the results from Box C on line for Item F-1. & & F-1 \\
\hline F-2 Estimated Economic Costs & & \\
Enter the results from Box D on line for item F-2. & & F-2 \\
\hline $\begin{array}{l}\text { F-3 Net Economic Benefit (Costs) } \\
\text { Estimated benefit on line for item F-1 minus estimated cost on line for } \\
\text { item F-2. Enter (F-1) - F-2) on line F-3. }\end{array}$ & & F-3 \\
\hline
\end{tabular}

\begin{tabular}{|l|l|l|l|l|}
\hline \multicolumn{1}{|c|}{ Net Dose } & Person-Rem & $\begin{array}{c}\text { Dollars/ } \\
\text { Person Rem }\end{array}$ & Dollars & Item(s) \\
\hline F-4 Net Dose Savings & & & & \\
$\begin{array}{l}\text { Enter the result from Box E and multiply } \\
\text { by } \$ \mathbf{2 , 0 0 0} \text { person-rem. Enter result on line } \\
\text { for item F-4. }\end{array}$ & $-\$ 2,000=$ & F-4 \\
\hline
\end{tabular}

Net Benefit

Net benefit on line F-3 plus the dollar value of the net dose savings on line for item F-4, i.e., $(F-3)+(F-4)$.

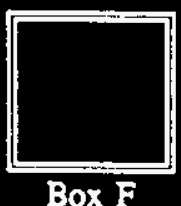

Box F

\begin{tabular}{|l|c|c|c|}
\hline Net Benefit Decision Index & Accept & Reject & Indifferent \\
\cline { 2 - 4 } $\begin{array}{l}\text { Depending on the value of Net Benefit, } \\
\text { circle one of the following: }\end{array}$ & $>0$ & $<0$ & 0 \\
\hline
\end{tabular}

If the net benefit is $>0$, accept the protective measure.

If the net benefit is $\leq 0$, perform an ALARA factor anlysis. 


$$
\text { WHC-SD-SNF-SP-010, Rev. } 0
$$

WHC-IP-1043, WhC Ocmpational ALARA Program

Section:

Figure 8-8. Upper-Level Net Benefit Evaluation.

\begin{tabular}{|l|l|c|}
\hline \multicolumn{1}{|c|}{ Cost/Benefit } & Dollars & Item(s) \\
\hline F-1 Estimated Economic Benefits & & \\
Enter the results from Box C on line for Item F-1. & -1 \\
\hline F-2 Estimated Economic Costs & & \\
Enter the results from Box D on line for item F-2. & & F-2 \\
\hline F-3 Net Economic Benefit (Costs) & & \\
Estimated benefit on line for item F-1 minus estimated cost on line for \\
item F-2. Enter (F-1) - F-2) on line for item F-3.
\end{tabular}

\begin{tabular}{|l|l|l|l|l|}
\hline \multicolumn{1}{|c|}{ Net Dose } & Person-Rem & $\begin{array}{c}\text { Doliars/ } \\
\text { Person Rem }\end{array}$ & Dollars & Item(s) \\
\hline $\begin{array}{l}\text { F-4 Net Dose Savings } \\
\begin{array}{l}\text { Enter the result from Box E and multiply } \\
\text { by } \$ 10,000 \text { person-rem. Enter result on } \\
\text { line for item F-4. }\end{array}\end{array}$ & - & $\times \$ 10,000=$ & - F-4 \\
\hline
\end{tabular}

Net Benefit

Net benefit on line F-3 plus the dollar value of the net dose savings on line $F-4$, i.e., $(F-3)+(F-4)$.

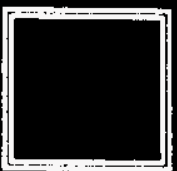

Box F

\section{Net Benefit Dexision Index}

Depending on the value of Net Benefit, circle one of the following:

\begin{tabular}{|c|c|c|}
\hline Accept & Reject & Indifferent \\
\hline$>0$ & $<0$ & 0 \\
\hline
\end{tabular}

If the net benefit is $>0$, proceed to Figure $8-9$ and perform the ALARA factor analysis.

If net benefit is $\leq 0$, either reject the protective measure or reevalunte the upper level net benefit using a case-specific value for the radiation detriment instead of $\$ 10,000$ per person-rem. 
WHC-IP-1043, WHC Occupational ALSL-SNF-SP-010, Rev. 0

Section:

Figure 8-9. ALARA Factor Analysis and Checksheet.

\section{ALARA Factor Analysis}

When the cost of an APM falls between the upper and lower limits of X, it must be evaluated against established ALARA factors. The following ALARA factors have been established for Westinghouse Hanford Company.

Evaluation of an ALARA factor analysis is determined by balancing the weighted "yes" answers against the weighted "no" answers. If there is a higher total of "yes" than "no," the APM is considered cost effective. If there is a higher total of "no" than "yes" the APM is not considered cost effective. The effort expended in quantifying these factors should be commensurate with the scope of the project.

1. Will the maximum individual doses for occupational workers exceed 10 mrem $(0.1 \mathrm{mSv})$ for the duration of the relevant timeframe?

\section{Weighting Factor: 3}

Discussion: This is an extrapolation of the negligible individual dose level recommended by the National Council on Radiation Protection and Measurements, 1 mrem $(0.01 \mathrm{mSv})$. The 1 -mrem $(0.01-\mathrm{mSv})$ dose cited by the report was in reference to nonoccupational workers; since occupational limits are traditionally a factor of 50 higher, a value of 10 mrem $(0.1 \mathrm{mSv})$ was selected. This does not indicate that $10-\mathrm{mrem}(0.1 \mathrm{mSv})$ effective dose equivalents are insignificant, but for defining individual factors to be used to assess the overall cost effectiveness of a measure, it is a valid consideration.

2. Does the APM maintain or decrease the current level of risk for occupational incidents or accidents?

Weighting Factor: 2

Discussion: APMs that increase the risk of occupational incidents or accidents possess an inherently negative factor.

3. Does the APM decrease the risk of environmental incidents or accidents?

Weighting Factor: 2

Discussion: APMs that decrease the risk of environmental incidents or accidents possess inherently positive factors. 


$$
\text { WHC-SD-SNF-SP-010, Rev. } 0
$$

$\begin{array}{llr}\text { WHC-IP-1043, WHC Occupational ALARA Program } & \text { Section: } & 8.0 \\ & \text { Revision: } & 0 \\ \text { Optimization Methodology } & \text { Date: } & 06 / 30 / 95 \\ & \text { Page: } & 16 \text { of } 24\end{array}$

4. Does the APM result in collective dose savings in the postoperational phase of operations?

Weighting Factor: 2

Discussion: APMs can affect the effective dose equivalents to be received in the postoperational phase of a facilities operation. If the proposed APM can be shown to reduce exposure during this phase, even if not quantifiable, this can be considered a positive factor in the overall process.

5. Does the APM result in cost savings during the postoperational phase of operations?

Weighting Factor: 1

Discussion: APMs can affect a facility in a variety of ways. If it can be shown that the APM will provide a future cost savings, even if not specifically quantifiable, such cost savings would be considered a positive aspect of the APM.

6. Does the APM increase the flexibility of personnel or other resources?

Weighting Factor: 2

Discussion: Certain APMs may not contribute to significant exposure reduction but would have a positive effect on facility operations. The APMs that affect entry requirements or other administrative controls should be considered in this area.

7. Does the APM result in an improved relationship with internal or external organizations?

Weighting Factor: 1

Discussion: If an APM can be said to improve the relationship between union and management, company and customer, or customer and outside oversight group, this is a positive consideration in evaluating the APM.

8. Does the APM decrease or not increase employee exposure to adverse working conditions or extreme discomfort?

Weighting Factor: 2

Discussion: Specific APMs often rely on additional protective clothing, masks, or other similar factors. When these factors result in adverse working conditions or extreme worker discomfort, this should be considered a negative aspect of the APM.

9. Does the APM reduce the release of radionuclides to the environment?

Weighting Factor: 3

Discussion: Reduction of radionuclides to the environment, even if existing levels are within current limits, is a positive factor in considering an APM. 
10. Does the APM improve or maintain current level of operability for an activity or facility?

Weighting Factor: 2

Discussion: If the implementation of an APM will restrict access to portions of a facility, curtail operations, or in some significant way hamper routine operations, this would be considered a negative aspect of the APM.

11. Is the adverse impact of the APM on the activity schedule minimal?

Weighting Factor: 2

Discussion: Implementation of an APM will invariably have some adverse impact on schedule. Only when the impact is extreme, i.e., a significant milestone is missed; should this be considered a negative aspect.

12. Does the APM contribute to waste minimization?

Weighting Factor: 1

Discussion: Waste minimization is a key concept of ALARA; therefore, any contribution to the waste minimization program is a positive factor to be considered. 
WHC-SD-SNF-SP-010, Rev. 0

WHC-IP-1043, WHC Ocqupational ALARA Program

Section:

8.0

Revision:

Date:

Optimization Methodology

Page:

18 of 24

ALARA Factor Analysis Checksheet

\begin{tabular}{|c|c|c|c|}
\hline Question & $\begin{array}{l}\text { Weighting } \\
\text { Factor }\end{array}$ & Yes & No \\
\hline $\begin{array}{l}\text { 1. Will the maximum individual doses for occupational workers } \\
\text { exceed } 10 \text { mrem }(0.1 \mathrm{mSv}) \text { for the duration of the relevant } \\
\text { timeframe? }\end{array}$ & 3 & & \\
\hline $\begin{array}{l}\text { 2. Does the APM maintain or decrease the current level of risk } \\
\text { for occupational incidents or accidents? }\end{array}$ & 2 & & \\
\hline $\begin{array}{l}\text { 3. Does the APM decrease the risk of environmental incidents or } \\
\text { accidents? }\end{array}$ & 2 & & \\
\hline $\begin{array}{l}\text { 4. Does the APM result in collective dose savings in the } \\
\text { postoperational phase of operations? }\end{array}$ & 2 & & \\
\hline $\begin{array}{l}\text { 5. Does the APM result in cost savings during the } \\
\text { postoperational phase of operations? }\end{array}$ & 1 & & \\
\hline $\begin{array}{l}\text { 6. Does the APM increase the flexibility of personnel or other } \\
\text { resources? }\end{array}$ & 2 & & \\
\hline $\begin{array}{l}\text { 7. Does the APM result in an improved relationship with internal } \\
\text { or external organizations? }\end{array}$ & 1 & & \\
\hline $\begin{array}{l}\text { 8. Does the APM decrease or not increase employee exposure to } \\
\text { adverse working conditions or extreme discomfort? }\end{array}$ & 2 & & \\
\hline $\begin{array}{l}\text { 9. Does the APM reduce the release of radionuclides to the } \\
\text { environment? }\end{array}$ & 3 & & \\
\hline $\begin{array}{l}\text { 10. Does the APM improve or maintain current level of } \\
\text { operability for an activity or facility? }\end{array}$ & 2 & & \\
\hline $\begin{array}{l}\text { 11. Is the adverse impact of the APM on the activity schedule } \\
\text { minimal? }\end{array}$ & 2 & & \\
\hline 12. Does the APM contribute to waste minimization? & 1 & & \\
\hline Total & & & \\
\hline
\end{tabular}


WHC-SD-SNF-SP-010, Rev. 0

WHC-IP-1043, WHC Occupational ALARA Program

Section:

Revision:

Date:

\section{APPENDLX B \\ EXAMPLE OF INSTALLING A CLOSED-CIRCUIT TELEVISION TO MONITOR THE SPENT FUEL POOL HEAT EXCHANGER ROOM}

\section{Part A: Radiological Problem Definition}

1. Describe the facility, its present radiological conditions, and the radiological activity of concern.

The facility is either a production, research, or test reactor. The radiological activity of concern is the routine inspection by operations of the spent fuel pool heat exchanger cubicle. The purpose of these routine inspections is to monitor for leaks and equipment malfunctions (visually). The radiation levels in the room are on the average $100 \mathrm{mrem} / \mathrm{hr}$ with hot spots of $1-10 \mathrm{rem} / \mathrm{hr}$.

2. Describe the proposed ALARA protective measure (APM).

These routine visual inspections could be performed remotely using a commercially available camera with a pan/zoom leas and a trainable (vertical and azimuth) mount and associated monitor/control panel.

3. Determine the relevant timeframe for estimation of cost elements and exposure impacts.

The relevant timeframe is 10 years based on the expected lifetime of the camera in the environment.

4. Identify the cost savings associated with the implementation of the APM, e.g., maintenance labor, operations labor, inspection labor, production, processing, salvage, reduced chemicals, reduced consumables, reduced radwaste.

Inspection labor savings of $5 \mathrm{~min} / \mathrm{day}$ or 30 hours/year. An operations labor rate, including overbead, is $\$ 335.00 /$ hour.

5. Identify the cost elements for implementation of the APM, e.g., design and engineering, equipment procurement, fabrication, installation or construction labor, operation, maintenance, associated training and procedure, additional chemicals, additional consumables, special tools, additional radwaste.

The cost for the camera, stand, and control panel is approximately $\$ 5,000$. It will require about 100 person-hours to install (50 person-hours in radiation area and 50 person-hours in a nonradiation area). Contractor labor to install and test is billed at a rate of $\$ 20.00 /$ hour.

6. Estimate the collective dose without the protective measure, with the protective measure, and to implement the protective measure. Determine, if possible, the maximum individual dose for the present or existing radiological activity.

The exposure impacts assuming all exposures associated with inspections are eliminated are:

Collective dose without protective measure: 3.000 rem

Collective dose with protective measure: 0 rem

Collective dose to implement protective measure: 5.000 rem

Maximum anoual individual dose: $1.5 \mathrm{rem} /$ year. 
WHC-IP-1043, WHC Occupational ALARA Program

Section:

Part B. Overriding Factor Analysis

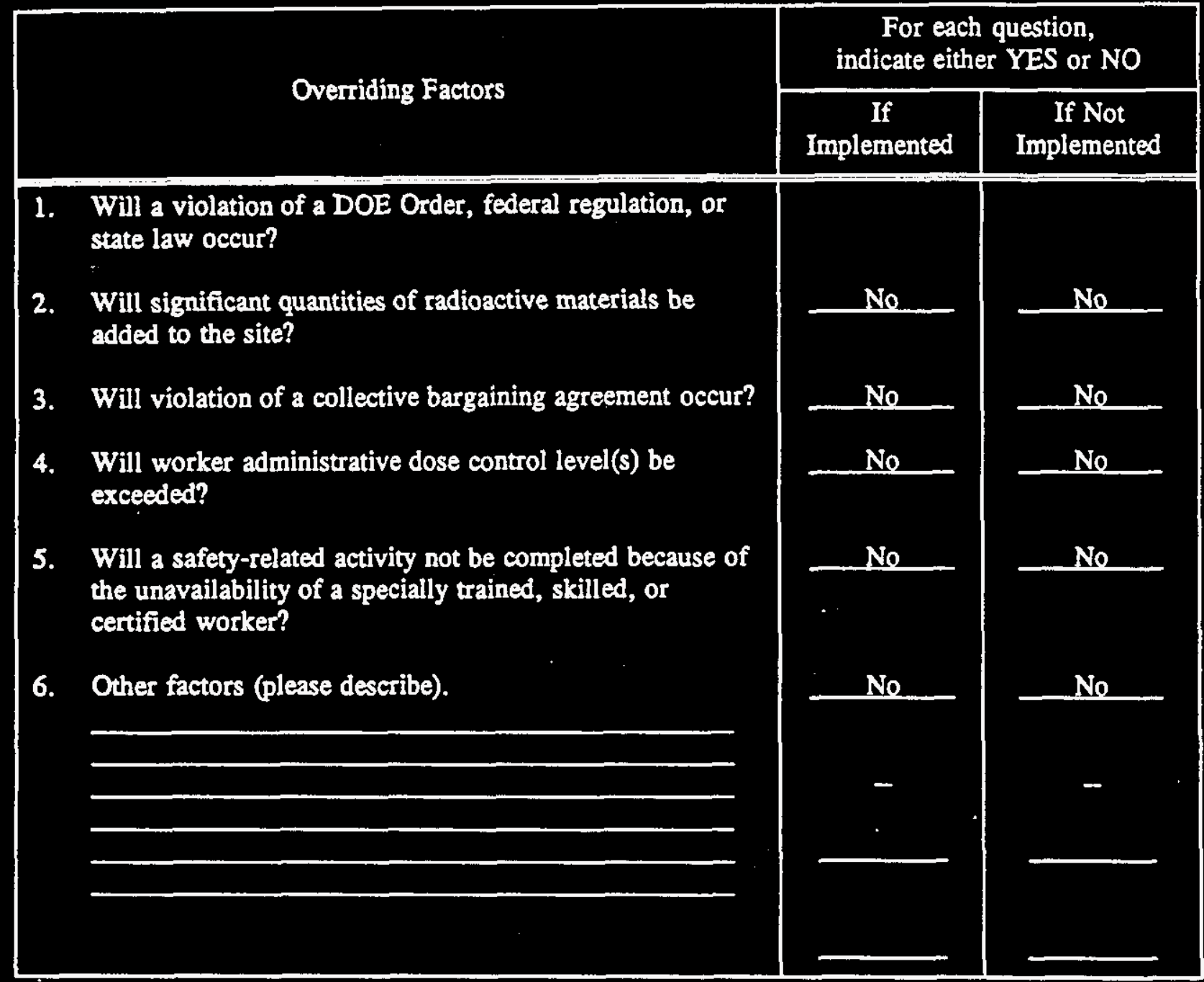

7. Conclusion (explain how YES answers to the above questions are overriding factors). No oxerriding factors apoly for the use of a remote video monitor in the snent fuel heat exchanger mubicle

9. Discussion (basis and references). 
Part C. APM Benefit Calculation

\begin{tabular}{|c|c|c|c|c|}
\hline Benefits & Qunntity & Unit Cost & Cost & $\operatorname{Item}(\mathrm{s})$ \\
\hline $\begin{array}{l}\text { C-1 Maintenance Labor } \\
\text { Enter the total estimated labor savings for the protective } \\
\text { mensure. Obtain the estimated total maintenance hours } \\
\text { saved. Obtain the appropriate dollar/hour rate for } \\
\text { maintenance. Enter the product(s) on line(s) for items C-1. }\end{array}$ & & & None & $C-1$ \\
\hline $\begin{array}{l}\text { C-2 Operations/Production Labor } \\
\text { Enter the total estimated operation/production labor savings } \\
\text { for the protective measure. Obtain the estimated total } \\
\text { operation hours saved. Obtain the appropriate dollar/hour } \\
\text { rate for operations. Eater the product(s) on line(s) for } \\
\text { items C-2. }\end{array}$ & & & None & $C-2$ \\
\hline $\begin{array}{l}\text { C-3 Inspection/Surveillance Labor } \\
\text { Enter the total estimated inspection/surveillance labor } \\
\text { savings for the protective measure. Obtain the estimated } \\
\text { total operation hours saved. Obtain the sppropriate } \\
\text { dollar/hour rate for inspection. Enter the product(s) on } \\
\text { line(s) for items C-3. }\end{array}$ & 30 hrs. & $\frac{\$ 35.00^{1} / \mathrm{h}}{I}$ & $\begin{array}{l}\frac{\$ 1050 / 4}{I} \\
\mathbf{1 0 y r} \\
\$ 10,500\end{array}$ & $C-3$ \\
\hline $\begin{array}{l}\text { C-4 Efficiency and/or Reliability Savings } \\
\text { Eater the total estimated savings associated with production } \\
\text { or processing improvements provided by the protective } \\
\text { measure. Enter the dollar amount of these savings on line(s) } \\
\text { for items C-4. }\end{array}$ & & & None & $C-4$ \\
\hline $\begin{array}{l}\text { C-5 Miscellaneous Savings } \\
\text { Eater the estimated savings from miscellaneous items (e.g., } \\
\text { salvage value of old equipment, reduced chemical and } \\
\text { consumable materials, reduced radwaste). Enter the dollar } \\
\text { amount of these savings on line(s) for items C-5. }\end{array}$ & & & None & C-5 \\
\hline
\end{tabular}

TOTAL ECONOMIC BENEFTS

Enter the total estimated benefits of the protective measure. Add all savings from lines for items $\mathrm{C}-1$ through $\mathrm{C}-5$, and eater total into Box C.
Grand Total $\$ \rightarrow$

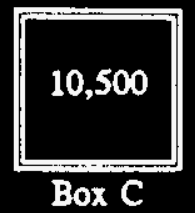


WHC-SD-SNF-SP-010, Rev. 0

WHC-IP-1043, WHC Occupational ALARA Program

Section:

Revision:

Date:

Part D. APM Cost Calculation.

\begin{tabular}{|c|c|c|c|c|}
\hline Benefits & Quantity & $\begin{array}{l}\text { Unit } \\
\text { Cost }\end{array}$ & Cost & Item(s) \\
\hline $\begin{array}{l}\text { D-1 Design and Engineering } \\
\text { Enter the total estimated design engineering cost for the } \\
\text { protective measure. Obtain the estimated hours to design and } \\
\text { engineer the productive measure. Obtain appropriate dollar/hour } \\
\text { rate for engineering. Enter the product(s) on line(s) for } \\
\text { items D-1. }\end{array}$ & & & None & D-1 \\
\hline $\begin{array}{l}\text { D-2 Capital Equipmeat, Fabrication, Material } \\
\text { Enter the total estimated capital costs of equipment, fabrication, } \\
\text { and materials for the new technique. Include "up front" hidden } \\
\text { costs such as R\&D, certification, patent rights, etc. Enter } \\
\text { product(s) on line(s) for items D-2. }\end{array}$ & & & $\$ 5.000$ & D-2 \\
\hline $\begin{array}{l}\text { D-3 Installation or Construction } \\
\text { Enter the total estimated labor costs to install the protective } \\
\text { measure. Obtain the estimated total hours of station and } \\
\text { contractor personnel to install. Obtain the appropriate } \\
\text { dollar/hour rate for station and contractor labor. Enter the } \\
\text { product(0) on line(0) for items D-3. }\end{array}$ & $100 \mathrm{hrs}$ & $\frac{\$ 20.001 /}{\mathrm{hr}}$ & $\$ 2,000$ & $D-3$ \\
\hline $\begin{array}{l}\text { D-4 Implementation: Procedure, Training, } \\
\text { Administrative Costs } \\
\text { Enter the estimated costs for training, procedure development, } \\
\text { and associated additional OsM protective measure (additional } \\
\text { O\&M being a negative savings obtained in lines C- } 1, \mathrm{C}-2 \text {, and } \\
\mathrm{C-3} \text { above from the difference between the existing and the } \\
\text { protective technique costs for operations, maintenance, and } \\
\text { inspection). Enter the product(s) on line(s) for items D-4. }\end{array}$ & & . & None & $D-4$ \\
\hline $\begin{array}{l}\text { D-5 Operation and Maintenance } \\
\text { Enter the total estimated cost to operate and maintain the } \\
\text { protective measure. Obtain the estimated hours to maintain and } \\
\text { operate. Obtain the appropriate dollar/hour rate for each work } \\
\text { group. Enter the product(s) on line(s) for items D-5. }\end{array}$ & & & $\frac{\text { Neqlioib }}{\text { le }}$ & D-S \\
\hline $\begin{array}{l}\text { D-6 Miscellaneous Costs } \\
\text { Enter the estimated total costs for miscellaneous items (e.8., } \\
\text { chemicals, consumable materials, special tools, additional } \\
\text { radwaste). Enter the product(s) on line(s) for item(s) D-6. }\end{array}$ & & & None & D-6 \\
\hline
\end{tabular}

\section{TOTAL ECONOMIC BENEETS}

Enter the total estimated benefits of the protective measure. Add all the costs from lines for items D-1 through D-6 and Grand Total $\rightarrow$

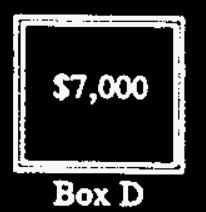
enter total into Box D. 
Part E. Dose Estimate.

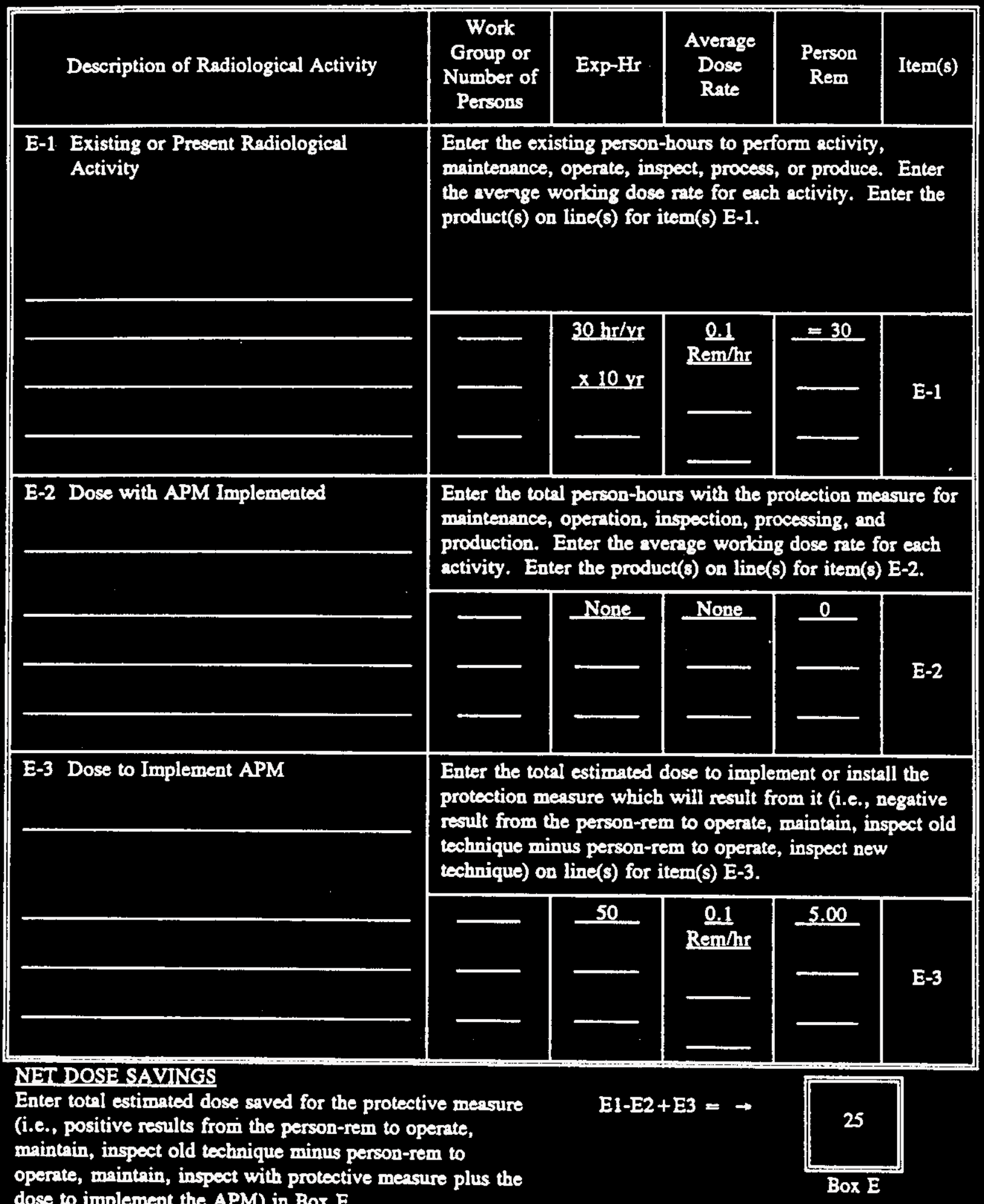


Part G. Upper-Level Net Benefit Evaluation.

\begin{tabular}{|c|c|c|}
\hline Cost/Benefit & Dollars & $\operatorname{Item}(s)$ \\
\hline $\begin{array}{l}\text { F-1 Estimated Economic Benefits } \\
\text { Enter the resulis from Box } C \text { on line for Item F-1. }\end{array}$ & 10.500 & $F-1$ \\
\hline $\begin{array}{l}\text { F-2 Estimnted Economic Costs } \\
\text { Enter the results from Box D on line for item F-2. }\end{array}$ & 7000 & F-2 \\
\hline $\begin{array}{l}\text { F-3 Net Economic Benefit (Costs) } \\
\text { Estimated benefit on line for item F-1 minus estimated cost on line for } \\
\text { item F-2. Enter }(F-1)-(F-2) \text { on line for item F-3. }\end{array}$ & $\mathbf{3 5 0 0}$ & F-3 \\
\hline
\end{tabular}

\begin{tabular}{|l|c|c|c|c|}
\hline \multicolumn{1}{|c|}{ Net Dose } & Person-Rem & $\begin{array}{c}\text { Dollars/ } \\
\text { Person Rem }\end{array}$ & Dollars & Item(s) \\
\hline $\begin{array}{l}\text { F-4 Net Dose Savings } \\
\begin{array}{l}\text { Enter the result from Box E and multiply } \\
\text { by } \$ 10,000 \text { person-rem. Enter result on } \\
\text { line for item F-4. }\end{array}\end{array} \quad 25$ & $\times \$ 10,000=$ & $\$ 250,000$ & $F-4$ \\
\hline
\end{tabular}

Net Benefit

Net benefit on line F-3 plus the dollar value of the net dose savings on line $F-4$, i.e., $(F-3)+(F-4)$.

\section{Net Benefit Dexision Index}

Depending on the value of Net Benefit, circle one of the following:

\begin{tabular}{|c|c|c|}
\hline Accept & Reject & Indifferent \\
\hline$>0$ & $<0$ & 0 \\
\hline
\end{tabular}

If the net benefit is $>0$, proceed to Figure 8-9 and perform the ALARA factor analysis.

If net benefit is $\leq 0$, either reject the protective measure or reevaluate the upper level net benefit using a case-specific value for the mdiation detriment instead of $\$ 10,000$ per person-rem. 


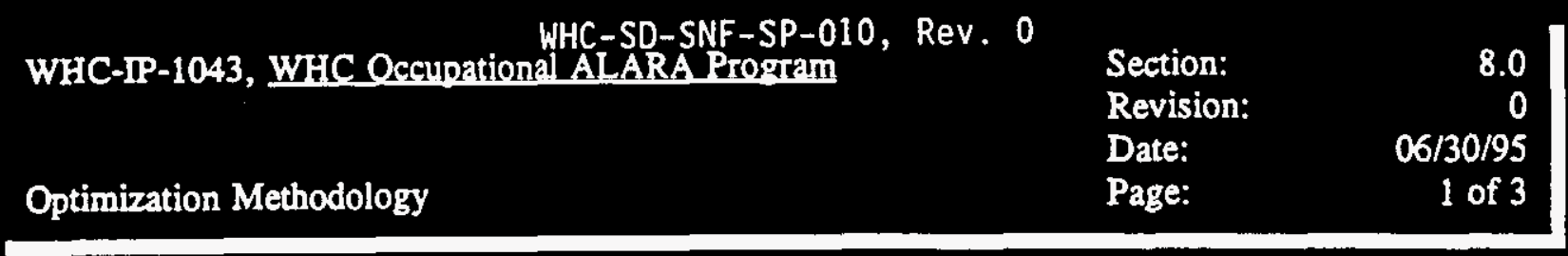

\section{APPENDK C}

\section{STEPS LEADING TO AS LOW AS REASONABLY ACHIEVABLE LEVELS}

Step 1: Define the Objective and Scope of the Issue to be Analyzed

State the objective of the project or proposal in terms which do not prejudge the means by which the objective is to be achieved. Specify the radiological protection factors to be included and those nonradiological protection factors to be brought into consideration.

\section{Step 2: Identify Protection Ontions}

Generate options for achieving the objective: the aim is to find options which are both practicable and environmentally acceptable. This step provides a strong incentive to consider not only obvious solutions, but also innovative alternatives. It also includes the elimination of impractical options.

\section{Step 3: Estimate the Performance of the Options for Each Factor}

Analyze these options to identify the advantages and disadvantages of each option. Use quantitative and qualitative methods when each are appropriate. Incorporate judgmental criteria explicitly.

Step 4: Analutical Solution

Present the results of the quantitative analysis of factors. Present the results of the evaluation concisely and objectively and in a format that can highlight the advantages and disadvantages of each option. Do not combine the results of different measurements and forecasts if this would obscure information which is important to the decision.

Step 5: Result of Optimization

Select the preferred option from the feasible options. The choice will depend on the weight given to the environmental impacts and associated risks and to the costs involved. Decision makers should be able to demonstrate that the preferred option does not involve unacceptable consequences to the environment. Include consideration of all relevant factors whether treated quantitatively or qualitatively, together with judgment on relative weighing and the results of sensitively analyses to select the recommended radiological optimum.

Step 6: Decision

Take account of the results of optimization and any nonradiological factors and make the decision. Scrutinize closely the proposed detailed design or operating procedures to ensure that no pollution or hazards have ben overlooked. It is good practice to have the scrutiny done by individuals who are independent of the original team.

Step 7: Imolement and Monitor

Monitor the achieved performance against the desired targets, especially those for environmental quality. Do this to establish whether the assumptions in the design are correct and to provide feedback for future development of proposals and designs. 
WHC-SD-SNF-SP-010, Rev. 0

WHC-IP-1043, WHC Occupational ALARA Progtam

Section:

Revision:

Date:

Throughout Steps 1 to 7: Maintain an Audit Trail

Record the basis for any choices or decisions through all of these stages; i.e., the assumptions used, the details of evaluation procedures, the reliability and origins of the data, the affiliations of those involved in the analytical work and a record of those taking the decision. Record, if possible, the reasons for any departure from the recommended optimum. 
Figure C-1. Structured Approach to ALARA decision making.

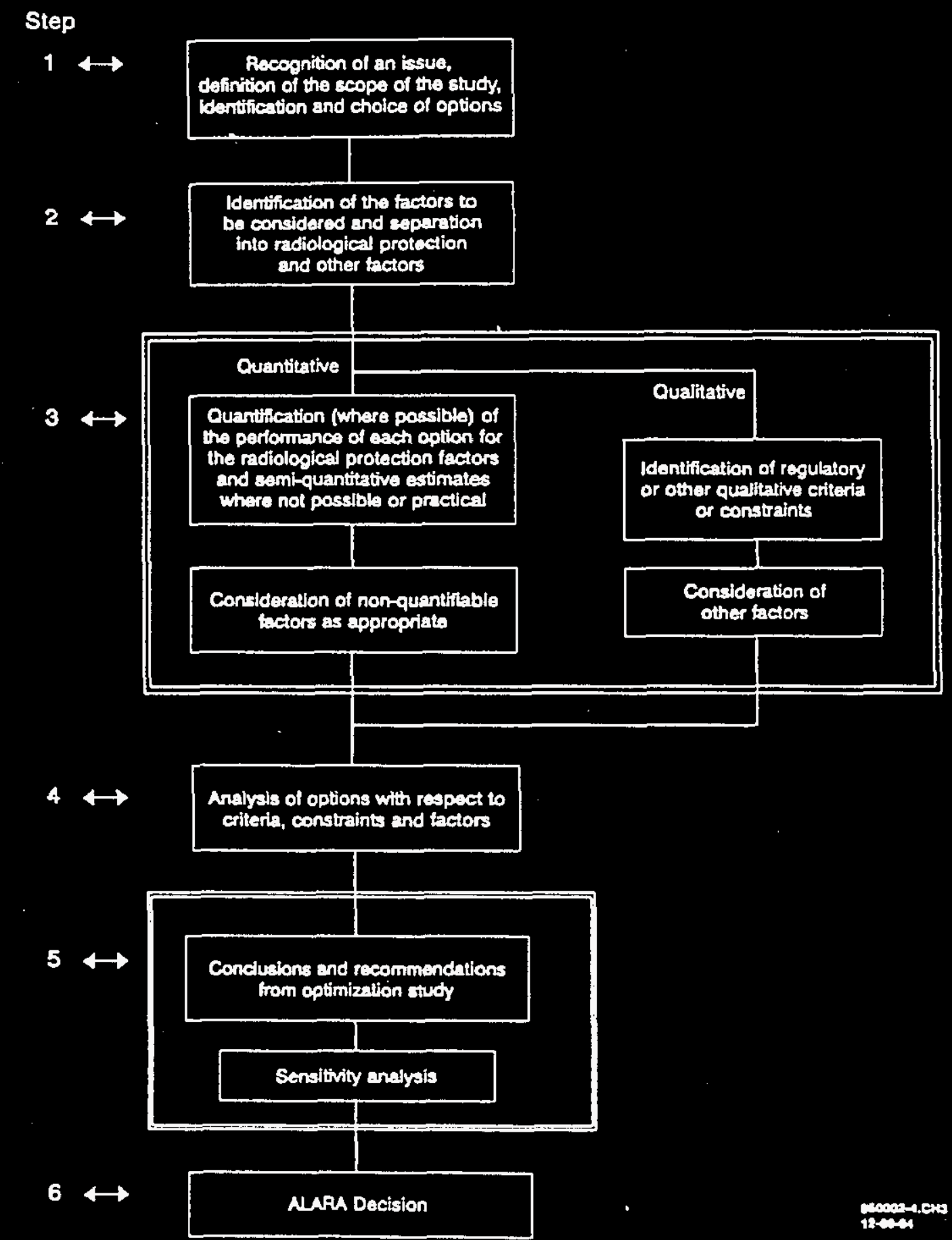


WHC-SD-SNF-SP-010, Rev. 0

This page intentionally left blank 
WHC-SD-SNF-SP-010, Rev. 0

\section{A.2 Appendix 3A of the Hanford Site Radiological Control Manual Checklist for Reducing Occupational Radiation Exposure}

\section{Preliminary Planning and Scheduling}

$\begin{array}{ll}\text { - } & \text { Plan in advance } \\ \text { - Delete unnecessary work } & \text { Determine expected radiation levels } \\ \text { - } & \text { Sstimate collective dose } \\ \text { - Schence jobs } \\ \quad \text { Select a trained and experienced work force } \\ \quad \text { Identify and coordinate resource requirements }\end{array}$

\section{Preparation of Technical Work Documents}

- Include special radiological control requirements in technical work documents

- Perform ALARA pre-job review

- Plan access to and exit from the work area

- Provide for service lines (air, welding, ventilation)

- Provide communication (sometimes includes closed-circuit television)

- Remove or shield sources of radiation

- Plan for installation of temporary shielding

- Decontaminate

- Work in lowest radiation levels

- Perform as much work as practicable outside radiation areas

- State requirements for standard tools

- Consider special tools, including robots

- State staging requirements for materials, parts and tools

- Incorporate Radiological Control Hold Points

- Minimize discomfort of workers

- Revise estimates of person-rem

- Prepare Radiological Work Permits

\section{Temporary Shielding}

- Design shielding to include stress considerations

- Control installation and removal by written procedure

- Inspect after installation

- Conduct periodic radiation surveys

- Prevent damage caused by heavy lead temporary shielding

- Balance radiation exposure received in installation against exposure saved by installation

- Shield travel routes

- Shield components with abnormally high radiation levels early in the maintenance period

- Shield position occupied by worker

- Perform directional surveys to improve design of shielding by locating source of radiation

- Use mock-ups to plan temporary shielding design and installation

- Consider use of water-filled shielding 
WHC-SD-SNF-SP-010, Rev. 0

\section{Rehearsing and Briefing}

- Rehearse

- Use mock-ups duplicating working conditions

- Use photographs and videotapes

- Supervisors conduct briefings of workers

\section{Performing Work}

- Comply with technical work documents and RWPs

- Post radiation levels

- Keep excess personnel out of radiation areas

- Minimize radiation exposure

- Supervisors and workers keep track of radiation exposure

- Workers assist in radiation and radioactivity measurements

- Delegate radiological control monitoring responsibilities

- Evaluate use of fewer workers

- Reevaluate reducing radiation exposures

- Compare actual collective dose against pre-job estimate

- Review work practices to see if changes will reduce dose

- Coordinate personnel at the job site to reduce nonproductive time 
A.3 ALARA Design Review Checklist

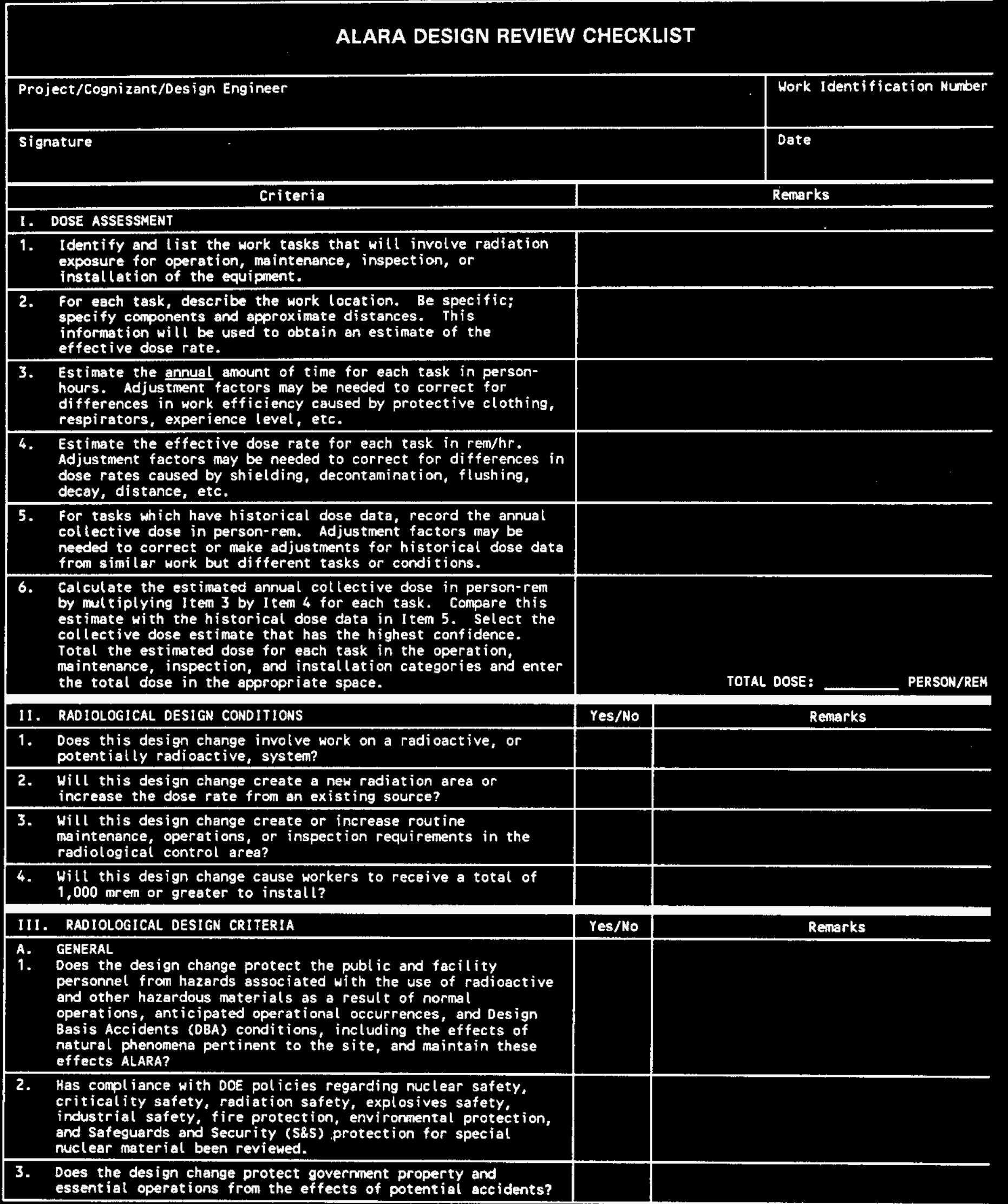




\begin{tabular}{|c|c|c|}
\hline III. RADIOLOGICAL DESIGN CRITERIA & Yes/No & Remarks \\
\hline $\begin{array}{l}\text { 4. Has the adequacy of planned radiation monitoring and nuclear } \\
\text { eritical ity safety instrumentation, including cons idering } \\
\text { whether the proposed instrumentat ion is appropriate for the } \\
\text { radiation types and intensities and whether it has suitable } \\
\text { redundancy and capabil ity for operat ion, both under normal } \\
\text { operat ing conditions and in emergency situat ions been } \\
\text { reviewed? }\end{array}$ & & \\
\hline $\begin{array}{l}\text { B. MATERIAL OF CONSTRUCTION } \\
\text { 1. Are the material specifications establ ished to decrease the } \\
\text { formation of activated corrosion products by specifying } \\
\text { materials low in cobalt and nickel content? }\end{array}$ & & \\
\hline 2. Are surfaces smooth and/or painted for easy decontamination? & & \\
\hline $\begin{array}{l}\text { 3. Are rough surface finishes such as crevices, hole, notches, } \\
\text { recesses, socket-head cap screws, and knurled finishes } \\
\text { avoided? }\end{array}$ & & \\
\hline $\begin{array}{l}\text { 4. Does the facility design and selection of materials include } \\
\text { features that facilitate operation, maintenance, } \\
\text { decontamination, and decommissioning? }\end{array}$ & & \\
\hline $\begin{array}{l}\text { C. SHIELDING } \\
\text { 1. Has design features and administrative controls been used for } \\
\text { facilities and equipment to keep radiation exposures in } \\
\text { controlled areas ALARA? }\end{array}$ & & \\
\hline $\begin{array}{l}\text { 2. Is shielding placed between serviceable components and any } \\
\text { substantial radiation source in the area? }\end{array}$ & & \\
\hline $\begin{array}{l}\text { 3. Has the combination of design features and administrative } \\
\text { control procedures provided that the total effective dose } \\
\text { equivatent does not exceed } 5.0 \text { rem per year? }\end{array}$ & & . \\
\hline $\begin{array}{l}\text { 4. If permanent shielding is not feasible, are provisions } \\
\text { incorporated for rapid installation of temporary shielding } \\
\text { (i.e., shield racks or supports)? }\end{array}$ & & \\
\hline $\begin{array}{l}\text { 5. Are external sources of radiation in areas of cont inuous } \\
\text { occupational occupancy }(2,000 \mathrm{hrs} / \mathrm{yr}) \text { been maintained below an } \\
\text { average of } 0.5 \mathrm{mren} \text { per hour? }\end{array}$ & & \\
\hline $\begin{array}{l}\text { 6. Are shields employed to prevent streaming of radiation through } \\
\text { doors, pipes, and duct penetrations (e.g., labyrinths or } \\
\text { shadow shields)? }\end{array}$ & & \\
\hline $\begin{array}{l}\text { 7. Is an adequate safety margin applied to seismic load analys is } \\
\text { to accomodate the additional load from temporary shielding? }\end{array}$ & & \\
\hline $\begin{array}{l}\text { 8. Has shielding calculations and design been verified to meet } \\
\text { ALARA requirements? }\end{array}$ & & \\
\hline $\begin{array}{l}\text { D. ACCESS CONTROL } \\
\text { 1. Are traffic pathways and areas that will be frequently used } \\
\text { located in low radiation zones? }\end{array}$ & & \\
\hline $\begin{array}{l}\text { 2. Is the design able to maintain personnel entry control for } \\
\text { each radiological area, commensurate with existing or } \\
\text { potential hazards within the area? }\end{array}$ & & \\
\hline $\begin{array}{l}\text { 3. Are areas of the facility which exhibit high occupancy, or are } \\
\text { presently uncontrolled, adequately protected from new or } \\
\text { increased radiation sources? }\end{array}$ & & \\
\hline $\begin{array}{l}\text { 4. Is maximum distance provided between serviceable components } \\
\text { and any substantial radiation sources in the area? }\end{array}$ & & \\
\hline $\begin{array}{l}\text { 5. Does the entrance to each access point to high and very high } \\
\text { radiation areas have the required control features (i.e., } \\
\text { locks, physical barriers, etc.)? }\end{array}$ & & \\
\hline $\begin{array}{l}\text { E. CONTAMINATION CONTROL } \\
\text { 1. Can containment be established to reduce the spread of } \\
\text { contamination, i.e., cribs, catch pans, drip pans, or } \\
\text { cofferdans? }\end{array}$ & & \\
\hline $\begin{array}{l}\text { 2. Are HEPA filters and/or charcoal used on the exhaust in areas } \\
\text { which have the potential for airborne radioactivity? }\end{array}$ & & \\
\hline $\begin{array}{l}\text { 3. Are the pressure gradient and airflow such that for flows from } \\
\text { areas of low potential for airborne radioactivity to areas of } \\
\text { higher potential for airborne radioactivity? }\end{array}$ & & \\
\hline
\end{tabular}




\begin{tabular}{|c|c|c|}
\hline III. RADIOLOGICAL DESIGK CRITERIA & Yes/No & Renarks \\
\hline $\begin{array}{l}\text { 4. Does the design incorporate features that will reduce the } \\
\text { likel ihood of cross-contamination of clean systems and } \\
\text { unmonitored release pathways? }\end{array}$ & & \\
\hline $\begin{array}{l}\text { F. SERVICE READINESS } \\
\text { 1. Is the equipment ready for service as received? }\end{array}$ & & \\
\hline $\begin{array}{l}\text { 2. Does the equipment require modification prior to installation? } \\
\text { If so, is the modification reflected in appl icable documents, } \\
\text { and can the modification be performed in a non-radiologically } \\
\text { controlled area? }\end{array}$ & & \\
\hline $\begin{array}{l}\text { 6. DOCUMENTATION } \\
\text { 1. Are a:l changes, revisions, modifications, and configurations } \\
\text { clearly reflected in appl icable documents? }\end{array}$ & & \\
\hline IV. OPTIMIZATION/COST -BENEFIT ANALYSIS & Yes/No & Remarks \\
\hline $\begin{array}{l}\text { 1. Is an opt imization anatys is necessary to show that the expense } \\
\text { (in terms of money, person-hours, dose to install and } \\
\text { maintain, etc.) of a project or feature of a project is } \\
\text { justified in terms of the actual benefit received? }\end{array}$ & & \\
\hline $\begin{array}{l}\text { 2. Summary of description and results of any cost benefit that } \\
\text { was performed. Include estimates of the net cost and net dose } \\
\text { over the expected life of the design change or modification: }\end{array}$ & & \\
\hline V. INCORPORATION AND DOCUMENTATION & & Renarks \\
\hline $\begin{array}{l}\text { 1. The results of the ALARA design review and the recommendations } \\
\text { for reduction shall be approved by line management. }\end{array}$ & & \\
\hline $\begin{array}{l}\text { 2. The recommendations adapted as a result of the ALARA design } \\
\text { review should be incorporated into the design or modification } \\
\text { package. }\end{array}$ & & \\
\hline 3. A copy shall be sent to the WHC ALARA Program office. & & \\
\hline \multicolumn{3}{|l|}{ Approved By } \\
\hline
\end{tabular}


WHC-SD-SNF-SP-010, Rev. 0

WHC-IP-1043, WHC Occupational ALARA Program

Section:

Revision:

Date:

Figure 9-2. Typical Flow Diagram for Factoring ALARA Consideration into Design.

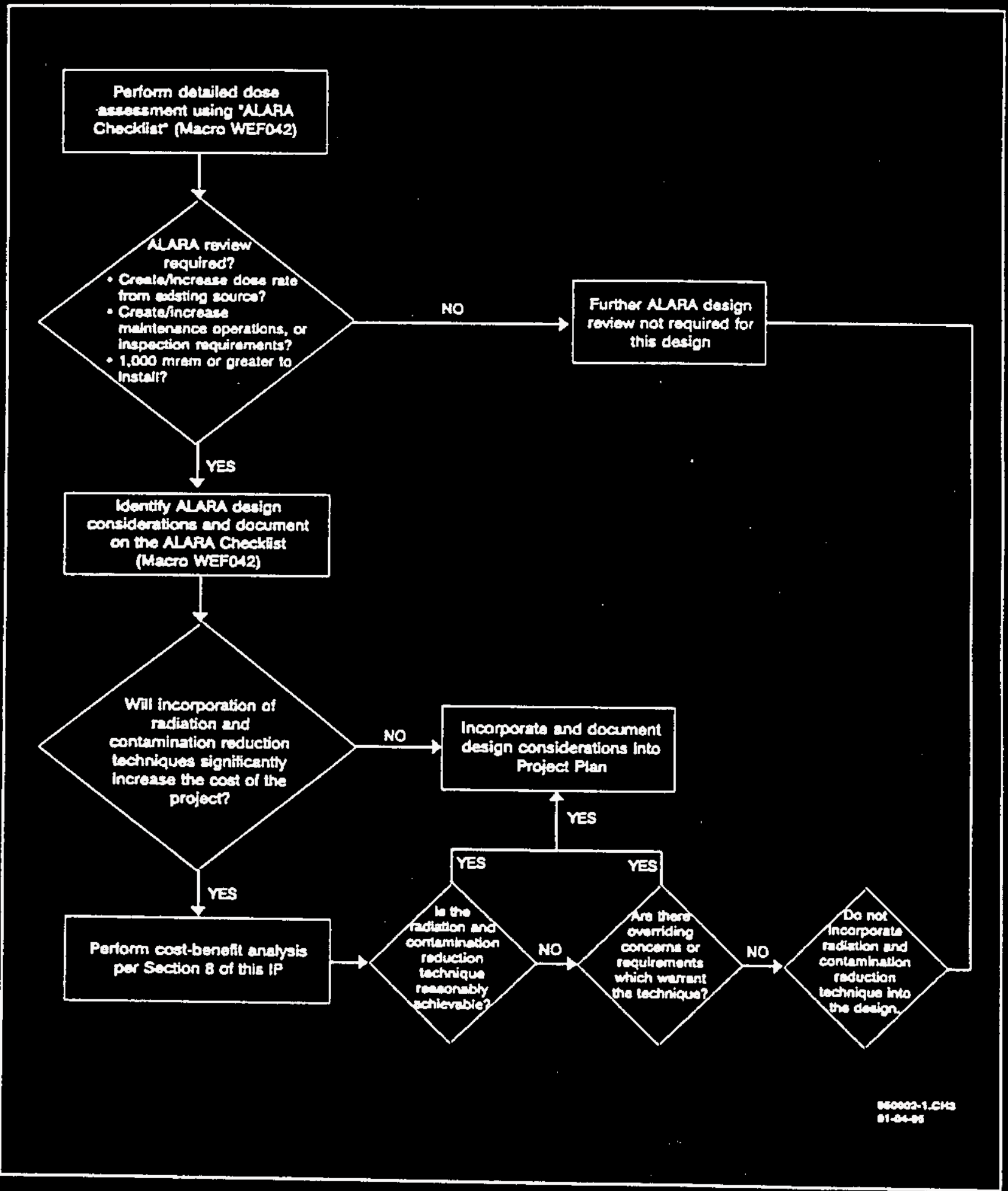




\section{DISTRIBUTION SHEET}

\begin{tabular}{|c|c|c|c|c|c|}
\hline \multirow{2}{*}{$\begin{array}{l}\text { To } \\
\text { Distribution }\end{array}$} & \multirow{2}{*}{\multicolumn{3}{|c|}{$\begin{array}{l}\text { From } \\
\text { Spent Nuclear Fue1 Project } \\
\text { Engineering Support }\end{array}$}} & \multicolumn{2}{|l|}{ Page 2 of 2} \\
\hline & & & & \multicolumn{2}{|c|}{ Date March 12, 1996} \\
\hline \multicolumn{4}{|l|}{ Project TitleMork Order } & \multicolumn{2}{|c|}{ EDT No. 615282 6/562 } \\
\hline \multicolumn{4}{|c|}{$\begin{array}{l}\text { WHC-SD-SNF-SP-010, Rev. 0, Spent Nuclear Fuel Project Dose } \\
\text { Management Plan }\end{array}$} & ECN No. $\mathrm{N} / \mathrm{l}$ & \\
\hline Name & MSIN & $\begin{array}{l}\text { Text } \\
\text { With All } \\
\text { Attach. }\end{array}$ & Text Only & $\begin{array}{l}\text { Attach./ } \\
\text { Appendix } \\
\text { Only }\end{array}$ & $\begin{array}{l}\text { EDT/ECN } \\
\text { Only }\end{array}$ \\
\hline $\begin{array}{l}\text { E. J. Shen } \\
\text { D. L. Sherrel1 } \\
\text { D. W. Siddoway } \\
\text { S. A. Slinn } \\
\text { D. W. Smith } \\
\text { K. E. Smith } \\
\text { J. A. Swenson } \\
\text { D. S. Takasumi } \\
\text { C. A. Thompson } \\
\text { D. J. Tompkins } \\
\text { L. O. Waggoner } \\
\text { M. J. Wiemers } \\
\text { M. E. Witherspoon } \\
\text { J. C. Womack } \\
\text { K Basins Project Files } \\
\text { SNF Project File } \\
\text { Central Files (Orig + 2) } \\
\text { OSII (2) }\end{array}$ & $\begin{array}{l}\text { R3-86 } \\
\text { R3-86 } \\
X 3-71 \\
\text { X3-74 } \\
\text { R3-11 } \\
\text { R3-85 } \\
\text { R3-11 } \\
\text { X3-85 } \\
\text { R3-85 } \\
\text { X3-74 } \\
\text { T0-06 } \\
\text { X3-85 } \\
\text { R3-85 } \\
\text { R3-86 } \\
\text { X3-85 } \\
\text { R3-11 } \\
\text { L }-84 \\
\text { E6-44 }\end{array}$ & 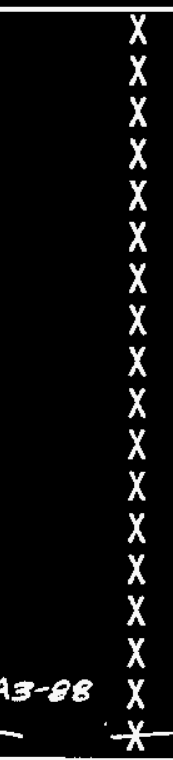 & & & \\
\hline
\end{tabular}




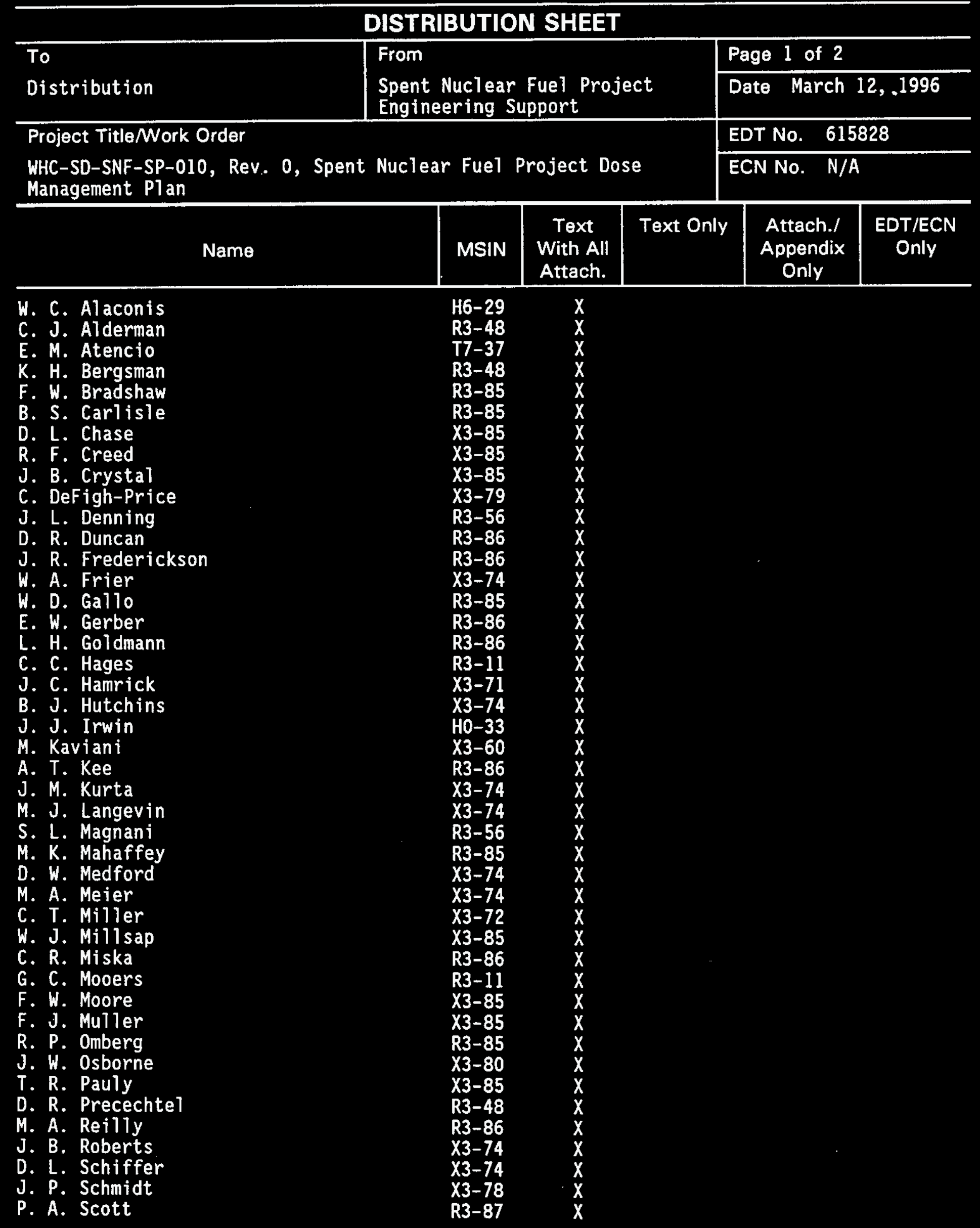

